\title{
Māori Performing Arts and the Weaving Together of Local, National and International Communities
}

\author{
By
}

Jonathon Avery

A thesis submitted to the Victoria University of Wellington in fulfillment of the requirements for the degree of Master of Ethnomusicology

2015

Te Kōkī New Zealand School of Music

Wellington

New Zealand 


\section{Table of Contents}

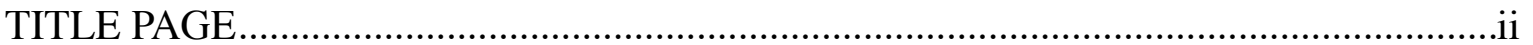

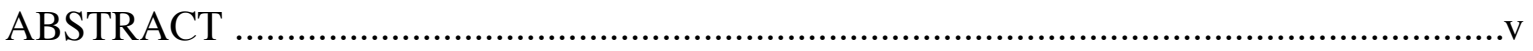

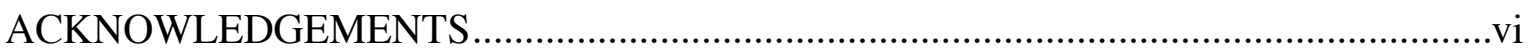

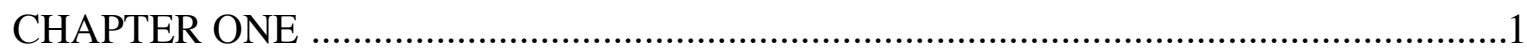

Cultural Research Areas

Social Research Areas

Methodology

Thesis Outline

CHAPTER TWO: Approaching the Field

Te Kōkī Māori Performing Arts Course

Ngāti Pōneke Young Māori Club

CHAPTER THREE: Learning Through Māori Performing Arts

25

The Ngāti Pōneke Young Māori Club

Te Kōki Māori Performing Arts Course

CHAPTER FOUR: Presentational and Participatory Performance .46

CHAPTER FIVE: Connecting to Aotearoa New Zealand .59

CONCLUSIONS 


\begin{abstract}
Māori performing arts provides a valuable contribution to Aotearoa New Zealand society. Māori performing arts has an intrinsic link to Māori culture and is used to connect 1) Māori who are disengaged from iwi/hapu/whanau, as well as 2) non-Māori, in New Zealand and around the world with Māori culture. Performance genres such as waiata-a-ringa, haka and mōteatea contain a body of knowledge that communicate Māori ways of being and doing and provide participants with an opportunity to become connected to a culturally literate and informed community. Using ethnographic techniques of participant observation, interviews and performance, this thesis examines the experiences of individuals who engage with Māori performing arts and the meaning they attribute to their engagement with the art form. Drawing on contemporary ideas of community and meaning, this thesis also investigates how Māori performing arts builds and strengthens relationships and whanaungatanga by connecting participants to local, national and international Aotearoa New Zealand communities. This thesis draws on two contexts in Wellington where people engage with Māori performing arts - The Ngāti Pōneke Young Māori Club at Pipitea marae and Te Kōkī New Zealand School of Music. Along with exploring two Māori performance context in detail, this these explores how Māori performing arts is used as a platform to educate participants about Māori knowledge, language and culture while also discussing how Māori performing arts is used to symbolise and represent Aotearoa New Zealand nationally and internationally.
\end{abstract}




\section{Acknowledgements}

I give my immeasurable thanks to everyone who assisted both directly and indirectly to this thesis. Firstly, I want to thank the members of the Ngāti Pōneke Young Māori Club for the support and hospitality you gave me weekly at Pipitea marae. I especially want to thank Tamihana Katene for your collaboration and time. I would also like to extend aroha to Eugene Ryder, Patricia Beamsley, Julia Forde and Miriama May Teinga for your kindness in sharing your experiences and journey's with me.

To my supervisor, Dr Brian Diettrich, I want to thank you for inspiring me as an undergraduate and triggering my interest in Ethnomusicology and research. Five years later, without your feedback, guidance, generosity, humor, and counsel this work would not have been possible. I could not have asked for a better supervisor.

I wish to express gratitude to my mum, Anna, who has always supported me with my ambitions and for keeping my mind and body nourished (especially with your famous roast dinners.)

Thank you to Victoria University of Wellington's scholarship office for the financial support to do this thesis, and to NZSM for assisting me with research costs throughout the year. Thank you to the lovely people of 11 Lawrence Road for your kindness and hospitality during the last months of my thesis writing.

Last, but far from least, thank you Erin for everything else. I am deeply grateful for your guidance and support and believing in me even when I did not.

To Dad and Matt, you are both deeply missed. This thesis is dedicated to you. 


\section{Chapter 1 Introduction}

\section{Prelude- Origins of this Thesis}

Lined up in our rows, we wait patiently on the steps of the wharenui. The person next to me silently practices the words, eyes closed and lips trembling to the beat of the syllables. Meanwhile, our tuākana quizzes us on our knowledge of the waiata we are about to perform in front of our lecturers. "what if I forget what the waiata is about," I silently question myself. In the near distance students fill the space in front of the marae as they wait their turn to perform in the wharenui. Accompanying them is the beautiful melancholic melodies of mōteatea that dance between the buildings surrounding Te Tumu Herenga Waka Marae, before floating away into the Wellington wind. "All right, next group." At once I'm brought back from my daze; "what if I forget the words?" "Good luck, whanau," our tuākana whispers as we enter through the front door to the wharenui. "Am I capable? Should I be here? Can I do this mōteatea justice?" are all questions running through my mind as we line up in front of two adjudicators and a video camera.

My performance group and I made it through the final assessment where everything from correct pronunciation, hand actions, vocal technique and competent knowledge of the pieces were assessed. I can vividly recall the unique sense of satisfaction I experienced after performing at Te Tumu Herenga Waka Marae that day. For a semester we routinely rehearsed and performed a variety of waiata in order to access mātauranga Māori and te reo to develop an understanding of te ao Māori. Completing this assessment was unlike the usual relief I had experienced after completing other university course requirements. This meant a lot more to me. It was then I realised that this was the first time, after attending secondary school in New Zealand, that I had taken the initiative to actively engage with te ao Māori. It was at this time, in my late teens that a change in thinking occurred for me.

I am a Pākehā New Zealander who grew up in the small city of Napier. As a teenager, I was not motivated by friends and family to engage with te ao Māori, nor was I required during my secondary school years to be knowledgable of contemporary Māori issues. What little Māori knowledge I did gain was received through New Zealand's mass media. For me, this formed a conceptual space for me that further distanced my relationship with te ao 
Māori. It was not until I moved to Wellington for tertiary study that Māori culture became something possible for me to engage with.

My focus on Māori music, as part of my Bachelors, Honours and now Masters degrees at Victoria University of Wellington, was a purposeful attempt at garnering knowledge absent from my formal high school education. My time at Victoria was spent researching historical and contemporary Māori music, however, I was eager to continue engaging with the performative and educational side of Māori performing arts. It was not until 2013 that a friend mentioned the Ngāti Pōneke Young Māori Club to me. Ngāti Pōneke is a Māori performing arts group that performs and competes around the country. At the first rehearsal I attended in 2013, I was treated to an exceptionally high standard of performance and a community of people who are passionate about sharing knowledge within the wider community. At Pipitea I met Tamihana Katene, who is both a lifelong member of Ngāti Pōneke and teacher of Māori performing arts at Te Kōkī New Zealand School of Music. After joining in with their rehearsals, I realised that Ngāti Pōneke could be included in the next part of my journey to learning te reo Māori and continuing to learn about te ao Māori. I concluded that further research could provide information on how Māori performing arts is used as a vehicle to access Māori culture and began to collaborate with Katene to devise a research project that included both of these contexts as ways of learning Māori ways of being and doing.

Ngāti Pōnkeke Young Māori Club and a Māori performing arts paper taught at Te Kōkī, New Zealand School of Music, offer two unique perspectives of how Māori performing arts can be used as a way to engage with Māori knowledge, language, culture and custom. While I am still at the beginning of my journey in learning the Māori language, I was committed to hear from those who are also at the beginning of their journey, students in the Introduction to Māori performing arts course, and those who have been engaging with Māori performing arts for a large portion of their life. These two case studies are drawn together by the fact that the people involved are accessing te ao Māori through the process of music performance.

Māori performing arts in the twentieth and twenty-first centuries is predominantly embedded within kapa haka performance (Papesh \& Ka'ai-Mahuta, 2013, 117). Kapa haka has allowed for the development of a new relationship between performance and identity. The demand for postwar labour opportunities saw a considerable amount of cultural dislocation as migrants became separated from supportive rural communities. This internal migration within New Zealand saw the emergence of Māori cultural clubs, sports clubs and religious and tribal associations (Peters \& Andersen, 2013, 307). The 1960s saw the widespread establishment of 
urban marae, which provided Māori with a location for celebrations and important ceremonies. Urban marae became spaces for voluntary association rather than kinship and descent like rural marae $(2013,308)$. Kapa haka, then, coincided with the urban drift to find work and was the beginning of the development of a modern Māori identity (Papesh \& Ka'aiMahuta, 2013, 120), and as Mazer (2000) concludes, a performance practice that has become "ubiquitous in the New Zealand cultural experience" (41).

In this thesis I will examine how Māori performing arts is an effective medium for learning various aspects of Māori culture and will explore how this medium is communicated. Borrowing the Māori cultural practice of weaving, I explore how Māori performing arts contains a body of knowledge that when learned and experienced, communicates Māori ways of being and doing and connects individuals to Aotearoa New Zealand. Engaging with Māori performing arts allows participants to become part of an informed, culturally literate community. This thesis privileges the voices and experiences of participants to reveal how Māori performing arts can effectively engage community groups and tertiary students with Māori knowledge, language, culture and custom.

\section{Cultural Research Areas}

\section{Māori Performing Arts}

The oral narratives of some iwi trace the origin of the performing arts to Tamanuiterā, the sun (Ka'ai-Mahuta, 2013, 5). In his book, Games and Pastimes of Maori, Best records the traditional narrative:

Tamanuiterā has two lovers, Hinetakurua, the winter maiden, and Hineraumati, the summer maiden, with whom he has a son called Tānerore. It is said that Tānerore dances for his mother during the summer months, when Hineraumati holds the favour of Tamanuiterā. The shimmering heated air that rises from the ground on hot summer days is personified as te haka a Tānerore (the dance of Tānerore) (Best 1925: 93).

The shimmering heated air is attributed to the modern-day performance of the wiri, and is said to be an acknowledgement of this ancestor (Gardiner, 2001). Wiri is a constant performance practice, seen in waiata and haka performance styles. This proverb is therefore recognised by many Māori performing arts groups in Aotearoa. There are myriad stories passed through the generations that describe the linage, genesis and function of the 
performing arts (Ka'ai-Mahuta, 2013), however, it is this story that is widely accepted across iwi and best describes the origins of haka (Best, 1925).

In scholarship, Māori performing arts has historically been referred to as 'haka' and performed predominantly by men (Gardiner, 2001), but it is important to note that Māori performing arts is continually expanding to incorporate a variety of functions, performance styles and compositions (Whitinui, 2010). Māori performing arts includes such performance styles as: whakaeka (entrance), waiata-a-ringa (action song), poi (swing tethered weights), mōteatea (chanting), whakawatea (exit) as well as haka. ${ }^{1}$ The most prolific performance context is kapa haka. 'Kapa haka' is a compound word; kapa, meaning 'row' and haka, meaning 'dance' (Williams, 1992). The Te Matatini Kapa Haka Aotearoa website (2013) describes kapa haka as both a competitive and noncompetitive performing art, primarily using the voice sung in te reo Māori.

The 'classic' literature includes Mervyn McLean's Māori Music (1971) and Traditional Songs of the Māori (2004), which approach Māori music from a historical perspective while Clement (1998), Gardiner (2001) and Karetu (1993) discuss haka, the most widely known style of Māori performance, in relation to Māori and New Zealand identity. Shennan (1984) and Waitoa (1970) give instructions on how to appropriately perform waiata-āa-ringa, an element of kapa haka performance. Davidson et al. (1996) discusses the junction of Māori culture, music and art and in a recent publication, Kia Ronaki: The Māori Performing Arts (Ka'ai-Mahuta, 2013), a number of scholars discuss the various components and genres that make up Māori performing arts.

The genesis of kapa haka is often credited to Sir Āpirana Ngata and Te Pou-iMangatāwhiri. As a member of the Massey Government, one of Ngata's obligations was to mobilise Māori behind the war effort, and in particular behind the Māori battalion (Grace; 2001, 55). Āpirana capitalised on the interest that young Māori were showing towards waiata â-ringa and accordingly organised concerts around the country to raise funds for the war effort. It was at this time that kapa haka became celebrated in New Zealand's wider consciousness as they were put to work farewelling soldiers and welcoming home (Pepesh \& Ka'ai-Mahuta, 2013, 126). Kapa haka groups were initially formed for the performance of waiata $\overline{\mathrm{a}}$-ringa, but other performances of haka and poi were later added (Pepesch \& Ka'aiMahuta, 2013, 126). Māori performing arts participants blur the audience/performer boundary. Accordingly, I build on Turino's (2008) concept of presentational and participatory performance and refer to the overlap that occurs during rehearsals at Pipitea marae. Today, Māori

\footnotetext{
1 The term waiata is sometimes used interchangeably to refer to all Māori music performance styles
} 
performing arts is not only used as a vehicle for entertainment, but also used as a way to preserve and transmit Māori knowledge and culture.

\section{Mātauranga Māori}

Contained within Māori performing arts genres such as mōteatea and haka is mātauranga Māori. Mātauranga Māori is often defined as traditional knowledge handed down from ancestors (tupuna, tipuna), rangatira, kaum, tua, kuia, tohunga, and knowledgeable people (Durie 1996; Williams 1997). It is an explanation of human behavior, based on tradition and handed down through generations. Charles Royal describes Mātauranga Māori as Māori knowledge that is:

created by humans according to the world view entitled 'Te Ao Mārama' and by the employment of methodologies derived from this world view to explain the human experience of the world $(1998,6)$.

It represents the access point through which humans apprehend and make sense of their reality. It is a knowledge tradition that has existed in Aotearoa for generations $(1998,11)$ and situated within the Te Ao Mārama world view. ${ }^{2}$ An alternative meaning of the word 'Māori,' other than a cultural label, is the definition of 'clarity' and 'transparency' (Moorfeild, 2011). The word mātauranga is used broadly to refer to 'knowledge,' thus, mātauranga Māori is a phrase used to communicate something distinctive, valuable and essential about the Māori world (Royal, 2012, 34). Māori performing arts is an interactive learning activity that combines oral histories and narratives with physical movements; it motivates participants to embody mātauranga Māori knowledge. Corporal movements not only encapsulate Māori knowledge and values, but also constitute an "awakening as well as a merging of all the senses"(Whitinui, 2010, 7). The shared experience of performing in unison is symbolic of Māori values of knowledge as something which is collectively owned and shared. Contained within waiata are stories, histories, values and beliefs which are brought to the fore through learning and performing.

\section{Te Reo Māori}

The decline of te reo Māori since Pākehā arrival in Aotearoa, has continued to affect every facet of Māori society and, as Rachel Ka'ai-Mahuta (2008) writes, the loss of language has

\footnotetext{
2 Royal refers to the Māori world view as the Te Ao Mārama world view. Te Ao Mārama represents the philosophical framework through which Māori history, both the Hawaiki period and Aotearoa period, exist (1998, 5).
} 
been one of the most devastating changes to the performing arts (165). ${ }^{3}$ The Education Ordinance Act, passed in 1847, was one of the first official government steps taken to implement racial amalgamation in the New Zealand education system (Calman, 2013). In 1900, ninety percent of Māori children starting school could speak fluent te reo. This is compared to 1979 where this number had decreased so much that it was believed te reo would soon cease to exist (Ka'ai-Oldman, 1988, 24). In 1987, the Māori Language Act was passed, declaring te reo Māori be an "official" language of New Zealand. Along with enabling the right of te reo be used in court proceedings, the Act also saw the establishment of The Māori Language Commission whose role, among other things, was to promote Māori language and its use as a living language, and as an ordinary means of communication (Peters, 2014).

In 2003, the Clark Government launched the Māori Language Strategy that outlines long-term goals and visions of the revitalisation of te reo Māori. Today, Māori performing arts is recognised at a state level as being an access point to Māori language, and in a recent Te Puni Kōkiri survey (2006), it is revealed that twenty-eight percent of the Māori adult population were involved in kapa haka in 2006 (2). Additionally, the study revealed that seventy-nine percent of people engaging in kapa haka were speaking at least some te reo in these contexts (2). The Government, while historically diminishing the rights of Tangata Whenua to speak te reo, have now recognised, with Te Puni Kōkiri's aid, the importance of Māori language education and the potential that Māori performing arts has in facilitating language learning.

Sustained Māori-lead activism has seen the genesis of language programs such as te kōhanga reo $^{4}$, kura kaupapa Māori ${ }^{5}$ and the introduction of te reo Māori and Māori Studies courses in tertiary education. In 2000, the Māori Television channel was established by Cabinet. In March 2004, Māori television began its transmission to over 70 percent of New Zealand households.

Māori performing arts provides both a means and an opportunity to engage with Māori language learning. Like history, Māori language was traditionally transmitted orally. It follows, then, that some Māori performing arts genres like waiata and haka are "the traditional

\footnotetext{
${ }^{3}$ Te reo Māori is closely related to other languages of Eastern Polynesia, such as Cook Island Māori, Tahitian and Hawaiian; evidence of which is found in the grouping of shared vocabulary items (Kāretu \& Waite, 1988). The arrival of Englishspeaking Pākehā to New Zealand shores has had some influence on te reo. This influence is heard when existing Māori words are extended to create new concepts (1988); an example of this is found in the word waka, meaning 'canoe,' which is now commonly assigned to more common means of transport.
}

${ }^{4}$ Conceptualised in 1981, Kōhanga reo (language nests) is a program run at pre-school age, taught exclusively by elderly Māori women who speak fluent te reo Māori. The intention of the program is to incorporate Māori culture into early childhood education, so that young children may be educated in both Māori and English (Mita, 2007).

${ }^{5}$ Kura Kaupapa Māori is as an education facility for children to attend at primary and secondary school level (2007). 
newspapers and history books of Māori society" (Ka'ai-Mahuta, 2008, 167). Language loss has resulted in a diminished understanding of the knowledge contained within waiata and haka, affecting the performers ability to convey meaning and emotion. Māori performing arts provides an incentive to engage with Māori language in order for the knowledge within the waiata to be disseminated.

\section{Iwi and Pan-Iwi Identity}

Iwi, as it is understood today, is an organised form of group-by-decent, or tribe (Maaka, 2003; cited in Gonzalez, 2010, 22). In Precolonial New Zealand, iwi acted as nations of people unto themselves, with a necessity for diplomacy and political stability (Mead, 2003, 221). Pan-iwi like Ngāti Pōneke began as a result of detribalisation after the mass migration of the 1940 (Gonzalez, 2010, 24-25). This connects with this thesis as Pipitea is a marae where all iwi affiliations (and non-Māori) are welcome to be part of Ngāti Pōneke. For urban groups such as Ngāti Pōneke, current constructs of iwi identity are, in part, attributed to processes of retribalisation after WWII and Ngāti Pōneke is "one of the first pan-Māori groups to call themselves an iwi, simply by calling themselves Ngāti Pōneke" (2003, 224). The tangata whenua of Pipitea marae is Te Āti Awa, which is recognised in the tikanga of Ngāti Pōneke members. Many members of Ngāti Pōneke are affiliated with other iwi and hapu, but identify with Ngāti Pōneke as their iwi and Pipitea marae as home.

\section{$\underline{\text { Social Research Areas }}$ Cultural Learning and Wellbeing}

This thesis builds on the number of case studies throughout Aotearoa that have paid especially close attention to music and musical meaning. In Whitinui’s (2007) thesis, Māori secondary school students are shown to develop "culturally responsive" and "culturally connected" education outcomes as part of engaging with kapa haka in mainstream schooling (ii). The implications for kapa haka engagement includes a growth in optimism and confidence in schooling, as well as affirming that the performing arts is able to affirm the student's identity as Māori. Similarly, in her dissertation, Paenga (2008) researches the relationship 
between wellbeing and kapa haka, investigating the impact that kapa haka has on Māori identity and the subsequent benefits this has for Māori health.

In a recently submitted doctoral thesis on the revitalisation of te reo, Peters (2014) found "culturally embedded activities" (220), such as kapa haka, were often found as providing a motivational force for language learning. In addition, participants signaled their desire to frequently use Māori words in kapa haka contexts, even in cases where their own ability to speak te reo Māori was limited, illustrating a desire to express a strong sense of Māori identity (Peters, 2014, 220).

A 2014 Manatū Taonga Ministry for Culture and Heritage report explores the contribution that kapa haka Māori performing arts gives to Aotearoa New Zealand society. It found that Māori performing arts provides an intrinsic link to culture and Māori identity, while playing an essential role in connecting people. It also found that Māori performing arts has an important function in the revitalisation of reo, tikanga, and ritual processes and histories (Manatū Taonga, 2014, 6). It concludes that kapa haka is a culturally safe way for all New Zealanders to engage with Māori culture, however, it is not given the status or respect it deserves by non-Māori and is consequently undervalued and treated in a tokenistic manner. The report also gives recommendations for future useful research areas, two of which are explored in this thesis: what are the benefits of kapa haka participation, and what are the experience of non-Māori who participate $(72,23)$.

\section{Imagined Community}

People who participate in Māori performing arts are embodying knowledge, and in doing so are part of Māori performing arts community or what Benedict Anderson calls the "imagined community" (2006) Anderson's seminal work in defining nation, nationality and nationalism emphasised the role of print in creating a collective feeling of fellowship in large groups of people whom have not had face-to-face contact with one another, still imagine themselves as a community. Māori performing arts fosters feelings of connectedness and nationhood to Aotearoa New Zealand community.

Anderson begins by describing nationalism as an "uncomfortable anomaly," due to its multiple meanings, and instructs the reader to consider nationalism as a cultural artifact rather than an ideology. Liberalism and fascism, for example, have close philosophical ideals assigned to them, whereas nationalism does not have coherent philosophies tied to it, yet everyone has a nationality. Anderson examines why nation-ness is so emotionally effecting and 
mobilsing of people when it does not appear to give a coherent list of conditions in which people are to commit and believe. For these reasons, nationalism should be discussed as a cultural category and thought of in an "anthropological spirit" (2006, 5). Writing in Imagined Communities, Anderson proposed:

[The nation] is imagined because members of even the smallest nation will never know most of their fellow-members, meet them, or even hear of them, yet in the minds of each lives the image of their communion...All communities larger than primordial villages of face-to-face contact (and perhaps even these) are imagined. Communities are to be distinguished, not by their falsity/genuineness, but by the style in which they are imagined...[The nation] is imagined as community, because regardless of the actual inequality and exploitation that may prevail in each, the nation is always conceived as a deep, horizontal comradeship. (6)

This term does not apply solely to nationalism. Anderson suggests here that imagined communities may be appropriate in theorising other communal forms, and this has continued into other fields of enquiry into ethnomusicology well beyond his own area of specialisation (Shelemay, 2011). Māori performing arts is the "imagined community" in three overlapping styles: local, national and international. Local groups like the Ngāti Pōneke Young Māori Club crystallise their local identity through performance and weekly engagement with the performing arts.

\section{Methodology}

\section{Kaupapa Māori}

The methodology for this research draws heavily on the Kaupapa Māori framework. Kaupapa Māori is a Māori-centered research framework that legitimises and privileges Māori practices, values and beliefs. Linda Tuhiwai Smith (1999) writes of the negative representations of colonial researchers in Aotearoa that began in the early stages of Māori/Pākehā contact. The negative effect of colonisation and the subsequent burden of the researchers "colonising gaze"(Hooks, 1992, 2) resulted in Māori skepticism towards research. Even though the approaches and understandings of cross-cultural research have significantly improved since first contact, there is still a framework needed which enables a safe and culturally affirming research praxis (Smith 1999; Carpenter \& McMurchy-Pilkington, 2008).

Driven by the desire to prevent further loss of language, culture and knowledge, the Māori renaissance of the 1970s saw Māori activism and autonomy brought to the fore. Māori 
scholars felt during this time that it was inappropriate for non-Māori to engage with Māori related research (Smith, 2012); a position that is necessary to halt the appropriation of Māori knowledge and ensure accountability rests on researchers and research participants (Bishop \& Glynn, 1992). Dominant Western paradigms of 'objective truth' were questioned by Māori activists and scholars, and a new approach was implemented by researchers with an inherent understanding that Māori have fundamentally different ways of viewing the world (Mahuika 2008, 4). Kaupapa Māori, then, provides a platform for which Māori can articulate their own realties, experiences and personal truths (4).

As a Pākehā researcher, I am aware of the enduring challenges from some Māori of the ethics surrounding Pākehā researcher involvement in Māori communities (Smith, 1999; Cram, 1993; Hill \& May, 2013). It is critical that when working cross-culturally, researchers understand the power dynamics that exist between them and their subjects $(1999,178) .{ }^{6}$ For these reason, my research framework is embedded within a cross-cultural research framework with a close attention to the values attributed to kaupapa Māori research. This thesis works within Chris Cunningham's (2000) Māori-centered research praxis where:

Researchers will typically focus on Māori development and will employ both Māori and nonMāori methods alongside other contemporary research tools. Contemporary analytical tools will be used as will some the developing Māori analytical tools, but a Māori analysis will be applied. (65)

During this research I collected data from Māori and non-Māori participants through observation and interviews. Māori analysis is applied and dual accountability rests on the researcher to meet the expectations of 'mainstream' reviewers and the expectations of Māori. ${ }^{7}$ Māori knowledge is produced through this type of research, yet measured with mainstream methodologies and paradigms (65).

The values and practices of kaupapa Māori framework are still included in Māoricentered frameworks, which validates and legitimises Māori practices, values and beliefs, with the inherent aim to ensure that the research will benefit Māori in all areas of society (Bishop 1997; Smith, 1999). Beginning in the 1980s, kaupapa Māori grounded itself in the developing and shaping of educational initiatives that would see culturally preferred ways of learning within education frameworks (Tapine \& Waiti, 1997). It is a research approach that values Māori epistemology over positivist, Western data collection (Cooper, 2012).

\footnotetext{
${ }^{6} \mathrm{I}$ also understand that my own interest in Māori issues does not warrant me immediate access to Māori communities or grant me the mandate to conduct Māori-focused research.

7 This research is mainstream because the final output is managed by Victoria University and specific requirements need to be met for examination purposes.
} 
Great care has been taken to follow the guidelines Smith (1999) gives for Māori researchers:

1) Aroha ki te tangata (respect for people);

2) Kanohi kitea (the importance of meeting face-to-face);

3) Titiro, whakarongo ... korero (look, listen ... speak);

4) Manaaki ki te tangata (be generous, share and host people);

5) Kia tupato (be cautious);

6)Kaua takahia te mana o te tangata (do not trample the mana of the people);

7)Kaua e mahaki (do not flaunt your knowledge) (Smith 1999, 124).

Smith also gives guidelines for non-indigenous researchers to consider when studying Māori issues where researchers should be aware of the powerful intervention that research has on the participants and wider community (178). ${ }^{8}$ I have adopted these research guidelines as a non-indigenous New Zealander while also working within the framework. I am working within a cross-cultural context and have taken extreme care to adhere to the guidelines set forth by Smith. I am also working within the research praxis outlined by Barnes (2013), which outlines a culturally appropriate framework for Pākehā-Māori research. Barnes notes the importance of Pākehā research reflexivity $(2013,25)$, which is found between the leaving of the Pākehā Eurocentric worldview and arriving at te ao Māori and privileging of mātauranga Māori. It invites the researcher to ask, who will benefit from the work being undertaken? How can one's own energy and the relationships that have been formed be sustained now and into the future? Within the context of reflexivity, the researcher should address questions about how collective relationships are negotiated and held (25).

\section{Research Design}

This research is influenced by Rachel Ka'ai-Mahuta's (2013) approach to the study of Māori performing arts. Ka'ai-Mahuta describes her approach to Māori performing arts through the analogy of a Tienga ${ }^{9}$, an elaborately patterned mat woven out of kiekie. This model highlights

\footnotetext{
8 I am aware that my choice to be involved in te ao Māori and Māori related research is a "choice", which for me, represents a form of "Pākehā privilege" (Barnes 2013, 17). Pākehā have the choice of opting in and out of this work, where as Māori are not always afforded this privilege. 9 Tîenga was used for ceremonial occasions such as consummating a birth, but was also used during karakia before men
went to battle $(2010,19)$. Tīenga is discussed in greater depth in chapter 3
} 
how different ideas are holistically woven together based on the practice of raranga, the art of weaving. This model reiterates the need for researchers in the field of Māori performing arts to understand that te ao Māori world, and concepts within it, do not exist in isolation, nor can they be understood in isolation of each other. Māori performing arts is deeply embedded within custom and daily social context. For example, most styles within Māori performing arts such as mōteatea, haka and karanga occur during regular marae ceremony.

My research makes use of a variety of qualitative ethnographic methods that lends itself to a multifaceted research design that includes collaborative research, semi-structured interviews and participant observation. Following other ethnomusicological practices, I include my own perspectives of participating in performing arts contexts. I am influenced by Barney and Solomon's (2009; 2012; 2013) autoethnographic research, that demonstrates a reflexive approach to cross-cultural collaborative research. The design of this research was done under the supervision (Cunningham, 2000) of Tamihana Katene, who is the teacher of PERF 151 and is on the Ngāti Pōneke Komiti and Parents Committee. I first consulted with Tamihana Katene in February of 2014, where we discussed a research topic that could be of use to Ngāti Pōneke and the future students of the NZSM Māori performing arts course. Katene has also acted as a principal consultant and collaborator (Horwitz, 1996, 137). One-toone semi-structured interviews were conducted to enable the voices and meanings of individual participants to be easily tracked (Smith \& Eatough, 2007). The post-interview method follows an Interpretive Phenomenological Analysis. which is most suited for studies involving personal and lived experiences to examine how people make sense of there personal and social world (2007). It uses a phenomenological lens (Giorgi and Giorgi, 2003), which situates itself within personal experiences and subjectivities (2007).

Much of this research is constructed around my own participation with the Ngāti Pōneke Young Māori Club and the students of the Introduction to Māori Performing Arts course (PERF 151). I draw heavily on Stephen Cottrell (2004) and Timothy Rice's (1994) methods of including participant observation in research. Cottrell, in his study of the professional music world in London, notes the importance of drawing on one's own experiences where appropriate $(2004,17)$, while Rice notes that personal experience is where "understanding begins" and "remains located"(1994, 10). For this reason, my research will include ethnographic approaches that include my own personal experiences. ${ }^{10}$ The experiences of the participants and the situations that I have observed are expressed, narrated and contextualised in a similar fashion to Aaron Fox's Real Country: Music and Language in

\footnotetext{
${ }^{10}$ I include lightly edited field notes throughout this thesis, which are presented in italics. This is used to distinguish my inner thoughts from those of my participants. For more information on the use of italics in ethnography see April Chatham-Carpenter's article, "Do Thyself No Harm": Protecting Ourselves as Autoethnographers (2010).
} 
Working-Class Culture (2004), where the contexualising of information is best conveyed by the speaker's face and body (39).

I am also influenced by Deborah Wong's (2004) critical approach to music ethnography and how her research is conducted with the intention and desire to engage with broader issues of society (9). In a music context, performance is an important site of "cultural production" $(2004,4)$ where realities are seen as being created through performance. While this thesis focuses on Māori performing arts, references to broader societal context are made where appropriate.

\section{Thesis Outline}

The structure of this thesis isolates three categories of Māori performing arts experience and connection to community: the individuals and their community music experiences, how the music is a gateway to connect communities, and what it is that individuals seek to procure from their music engagement.

Chapter two introduces the two Māori performing arts communities that are the foundation of this thesis: the introductory Māori performing arts course taught at Te Kōkī New Zealand School of Music and the Ngāti Pōneke Young Māori Club located at Pipitea marae. Through participant observation sourced from journals, I provide context to these communities who practice Māori performing arts today

Chapter three discusses and describes the process of learning Māori performing arts in both communities and how it is a gateway to educate participants about Māori culture, knowledge, language and custom.

In chapter four I explore how Māori performing arts is utilised at the Ngāti Pōneke Young Māori Club. I describe the differing views on what aspect of Māori performing arts should be of focus: participatory or presentational performance.

Chapter five investigates the various motivations that participants have for engaging with Māori performing arts.

Finally, in the conclusions I bring together the main theme of this thesis: the connection and affinity that individuals feel to community when engaging with music that is representative of Aotearoa New Zealand. 


\section{Chapter 2}

\section{Approaching the Field}

In this chapter, I introduce two settings where people experience Māori performing arts in Wellington. Participant observation was the primary method used during the field research. I am influenced by the practice of reflexive ethnography, beginning with John Miller Chernoff's (1979) African Rhythm and African Sensibility and Rice (1994) in recognising the dual responsibilty that researchers have in collecting information and forming relationships in the community. The fieldwork in this thesis was completed over eighteen months, which included countless rehearsals with Ngāti Pōneke, an excursion to Ngaruawahia and half a dozen performances in the Wellington community. In the New Zealand School of Music setting I draw on my experiences from the 2014 course that I experienced as a researcher for three months, but at times refer to the 2010 course that I undertook as an undergraduate student. While introducing the two settings and giving a summary of each, this chapter draws on my own experiences as both researcher and participant.

\section{Te Kōkī Māori Performing Arts Course}

As we conclude another run-through of the waiata, I look over and study Tamihana's reaction. Pen in hand, I prepare myself for some constructive comments. "OK guys, just a couple of corrections we need to go over, we're saying 'towe' again...it's 'tau', not 'towe'." The sound of "Taao," "Toe,"

"Teoa" is parroted around the room as the students and I try to correct our mistake. "Nah, nah, 'taaaoooo, taaoo, tau,' ka pai," he asks. "Ai," we reply. "Ka pai!?” Tamihana asks, this time searching for more assurance. "Ai!" we declare with more conviction. Still uncertain whether I 
will remember Tamihana's pronunciation, I add another note to my word sheet, reminding myself to separate my vowel sounds. The student sitting next to me adds to his deluge of pencil marks, underlined words and musical cues on his page, which appears to be nothing more than a cryptic puzzle. "In the Māori language," Tamihana continues, "our vowel sounds are much more open. You all need to open your mouths more, also, the rangi goes up on this word, there is a quick change in tempo as well. I'll show you." With half a breath he sings the line "I kapakapa, tu ai te tau o taku ate," emphasising the part of the rangi that we forgot to add. "Here we go. From the top again. Who wants to lead it?" Tamihana asks for about the fifth time today. Silence hangs over the room as the students divert their heads to avoid any eye contact with Tamihana that might suggest they would like to volunteer. "All right whanau, I'll lead it again, but one of you will have to lead it for the final performance, ka pai?" "Ai," they mutter with concession.

Each time we begin the waiata there is a moment of silence; a slight hesitation before we begin to sing. For most of the students this is their first intensive engagement with Māori performing arts, and with only ten students in the class, each voice is distinguishable and exposed to critique. Critiqued not only in the musical sense of pitch, timbre, tone and timing, but judged on pronunciation of te reo. One student is finding it particularly difficult, "I just get really tongue twisted with some of the pronunciations of Māori words," the student explains to me after class. "Sometimes my mouth doesn't really shape easily to certain sounds because I'm not used to pronouncing them and I guess I get a bit nervous about pronouncing the words in front of a Māori person who knows the language so well." But this apprehension that some students experience is predominantly self-imposed as Tamihana is exceedingly supportive and patient, while also making sure the class moves at a suitable learning speed.

The students' frantic preparation for the final performance reminds me of the Māori music performing arts course that I completed in 2010. This time, however, I am taking the class as a researcher. I am interested in the experiences of the students in the class and whether engaging in Māori music will lead to other understandings of Māori culture and maturanga Māori. The aim for me as a student researcher is to balance my own participation and learning with 
observations of other students in the class. I am eager to learn from Tamihana, but I also need to observe the commonalities of shared experiences in order to present individual voices within the research.

\section{Overview of the Course}

The Introduction to Māori Performing Arts course has changed from when I was enrolled as an undergraduate in 2010. At that time it was a joint venture between Te Kawa a Māui and the New Zealand School of Music and lectures were held at Te Tumu Herenga Waka Marae. The course garnered an eclectic group of students due to there being three different subject streams learning the same material. It included students studying towards bachelors of Māori studies (MAOR 125), bachelors of Music (PERF 151) and those who were interested in gaining Tohu Māoritanga (MAOR 802); a diploma in Māoritanga. This last course, taught by TeUrikore Biddle and Brian Diettrich, allowed those students to act as tuakana or teina to gain experience teaching waiata to those who are unfamiliar with Māori performing arts and te ao Māori. With about sixty students in the class, we were able to break up into small performance groups of ten and build strong relationships with that would strengthen our final performance.

The pieces that we perform in each course were dependent on the kaiako's iwi affiliations; Katene preferred to teach songs written by Ngāti Toa composers, while Biddle introduced students to Māori culture through the lens of Ngāi Tūhoe waiata and composers. Similar between the two courses is the learning outcomes. The course is intended to provide a base of knowledge for traditional and contemporary waiata performance within the context of the marae. Students who successfully complete and pass the course would gain an understanding in the following:

- Understand some of the basic values between Māori culture, society and performance

- Appreciate the essential elements of Māori language, custom, ritual, spirit and traditional chants in Māori performance

- Be able to execute at least three types of traditional Māori performance

- Reflect upon the inter-relationship between theory and practice of traditional and contemporary performance within a whānau environment or setting

- Access the written literature of song texts, descriptions of song types and other writings on Māori music

- Gain an understanding of the use, design and revitalisation of traditional Māori musical instruments

- Introduction to elements of music studies and performing arts. (Biddle, T, 2010) 
These learning goals were achieved using a number of practical and theoretical assessments throughout the twelve-week course. The assessments included four in-class waiata performances, which were judged on the standard of our individual and group performances, as well as a general understanding of the waiata's history, style, form and structure. Additionally, students were required to attend a noho marae at Ako Pai Marae on the Karori campus. This provided students with the opportunity to "put into practice" what they had learnt about marae practices throughout the course, while also providing students a space to whakawhānaungātanga. At the noho marae we were also given a presentation on taonga pūoro and granted the opportunity to practice for our upcoming practicums. Almost identical in learning outcomes, Tamihana's did not include a noho marae, however, the final assessment is performed at Pipitea marae with Ngāti Pōneke as the audience. ${ }^{11}$

In summary, the learning objectives of the course are for students to experience Māori culture through the performing arts. The outcome of this experience is to understand and appreciate the "essential elements" of Māori culture. The processes of learning "Māori language, custom, ritual, spirit and traditional chants in Māori performance," is a point of access for students to Māori ways of being and doing. Waiata connects students to Māori community and enables them to develop an understanding of culture and language (2010).

\section{Learning Through Experience}

"All right whanua. haka time!" Katene instructs, this time with slightly more enthusiasm and colour in his voice. The students flip through their notes to find the words to Ka Mate, arguably the most well-known Māori haka in Aotearoa. Max, a student from Auckland has been given the task of leading the haka for the final performance. After a knowing nod from Tamihana, Max begins, "ki ki ki ka ka ka kauana." The rest of the students gradually join in with him and experiment with their own voices, finding a vocal tone that will resonate the body and produce a unified texture that is loud and energising. A trade off is taking place. They need to find the right vocal aesthetic, one that requires a vast amount of air to be pushed through the diaphragm, while also conserving energy for the most passionate part of Ka Mate, the ending. As they find their correct voice, the class becomes louder and more unified. Some choose to keep themselves in time by lightly tapping their feet on the ground, while others tap

\footnotetext{
${ }^{11}$ Due to scheduling issues, the final performance did not occur at Pipitea marae in 2014 and was instead held in the VUW recreation room.
} 
their pens on their open notebooks, emphasising the unique triplet rhythm of Ka Mate's opening phrase. The students who are lacking practice are easily recognisable; their heads buried in their notes trying to make sense of the complex rhythms and uneven word phrasings. Most of the students have a background in musical theory, however, the class must learn this haka aurally. The technique for learning this piece is repetition of the haka at home with the accompanying recording that Katene has given us. On this occasion, Katene is concerned with perfecting the words to Ka Mate. We are instructed to perform it a couple more times, before he gives us a few helpful instructions to consider while practicing the haka out of class. "OK guys, tell me, who composed ka mate?" "Te Rauparaha” a few students reply. "Ka pai. Okay, now I'll tell you the story and the meaning behind the haka. You see, in my culture...in Māori culture...you need to be passionate when you perform, you need to put all of your body and soul into your performance. For you to be able to do that, you need to know the meaning behind the words and for what reason it was composed." For many students, this is the most rewarding part of the class is when Katene describes, in great depth, the contexts of the waiata that he teaches, the genesis of the landscape and geography of the Wellington region, as well as the spiritual and emotional connections that he has to Māori music performance. "Story time," is how Payal, a visiting student from North America, playfully labels Tamihana's narratives:

It sounds a little silly said out loud, but I think my favorite part is just listening to Tamihana tell us stories...I'm always a little bit weary about learning history from only one source, it's pretty easy to hear about New Zealand's history from the western perspective, you just go to the library. I'm not saying that Tamihana represents the whole entire Māori history, but I'm glad that I got to see it from another perspective besides the western one. (P. Patel, Personal Communication, May 4, 2014)

For Payal, the other students, and myself, the most beneficial part of the class is when Katene presents his perspective of Māori history. Katene continues explaining the origin of Ka Mate, "you see my tribe, Ngāti Toa, didn’t always live in the Porirua area:"

the iwi used to inhabit kawhia a part of the country that had very fertile and sought after land. It was because of this that many neighboring tribes would battle for their land. It was during this time that Te Rauparaha was born. The mother was from Ngāti raukawa and the father was Ngāti Toa. Their fifth child, a boy was born with six toes, that was the sign of a taniwha, he would be a great leader.

After mentioning a significant Māori concept or person of importance, Katene will explain the meaning behind various parts of Ngāti Toatanga and Māoritanga more generally. These are the moments of the class where the transfer of Māori knowledge to students flourishes. Katene's knowledge is now able to converge with our own experiences of performing $\mathrm{Ka}$ Mate, which in turn helps us formulate a conceptual map of te ao Māori. Aware that they may at some stage be tested on this information the students take notes as Katene continues to orate the origin of Ka Mate: 
Te Rauparaha's leadership stood out amongst his peers. He was a leader in the making. He grew to be a top fighting chief for Ngāti Toa as there was constant pressure from neighboring tribes to grab hold of Ngāti Toa homelands. To help fight off the neighboring tribes, Te Rauparaha travelled south, over hostile land, to Lake Taupō to form an alliance with the Ngāti Tuwharetoa tribe. While navigating his way south, a war party from Ngāti Te Aho pursued in an attempt to seek revenge for a previous incident involving Ngāti Toa. Considering this, Mananui Te Heuhue, the cheif of Tuwharetoa, could not grant Te Rauparaha refuge because of his wife's close connections with those who were persuing him. Mananui directed Te Rauparaha to seek refuge with a relative of his, Te whararangi who lived near Lake Rotoaira. Te Wharerangi reluctantly agreed to assist te Rauparaha and as the war party closed in on their settlement, he instructed him to hide in the food storage pit and for his wife, Te Rangikoaea to sit on top of it. The spiritual qualities of a woman and food would weaken the incantations of the tohunga that was accompanying the war party. Meanwhile, Te Rauparaha began softly chanting, "ki ki ki ka ka ka," as the tohunga meticulously searched the settlement. These lines were repeated many times, thwarting the powers of the tohunga, leading the war party to be convinced that he had escaped to Taranaki. As the sun broke the night sky, it was then that Te Rauparaha began the second verse, "ka mate ka mate, ka ora ka ora," thanking the woman for her spiritual powers and fetching the sun causing it to shine again. ${ }^{12}$

"I love these last few lines- nana nei i tiki mai whakawhiti te ra, which literally means the hairy man has caused the sun to shine." Katene will often give the class a direct translation from reo to English, then contextualise the metaphorical meaning of each word.

"All right whanau, lets clear these chairs out of the way and have a go at the actions," Katene instructs. As there are different actions for men and women, we break up into two groups and Katene shows them to us step by step. He steps his feet apart and squats down into the first position of the Ka Mate. "OK guys, monkey see, monkey do," he says with a smile. Finding a pocket of space amongst the gamelan instruments, we follow suit. Resting all our weight onto our knees and thighs we squat. "You need to get lower than that...nope, even lower. Bro, put your legs further apart!” he directs me. Five of us standing in a semicircle, we follow Katene's actions as he faces away from us, performing Ka Mate to the wall at half speed. As we start to get into the spirit of Ka Mate, he signals to us to perform at quieter volume due to other staff and students in proximity to the class room. Katene reminds us that he has booked the recreation room at the University fitness centre for us next week so we can go "all out." Moving through the different actions, Katene explains the relationship the actions have to the words. "When we get to puhuruhuru, our arms over lap like this," Tamihana lowers his left arm in line with his knees and moves his right arm between his left arm and torso. The actions are used to help emphasise the words, and this particular action is used to illustrate puhururu, the man who has been saved. "remember guys, keep that wiri

\footnotetext{
12 Some of the historical information in this except is based on the documentary Ka Mate the Hake the Legend (2011) directed by Wiremu Grace
} 
going, if you stop the wiri you're essentially not living!” As the class ends, Tamihana remind us of the looming final performance and encourages us to practice at home in front of the mirror.

\section{The Ngāti Pōneke Young Māori Club}

My first visit to Ngāti Pōneke Young Māori Club was September 4, 2013. Monday night practices take place at Pipitea marae which is situated in Thorndon, central Wellington. A week earlier I had been invited along by Katane, who acts as chair of the junior parents committee, to participate in an open session at Pipitea. I walked through the side door into the dinning area where everyone was setting chairs and preparing for practice a $6 \mathrm{pm}$. Katene showed me around the marae and introduced me to some of the parents. Noticing that I had brought my guitar to the marae, one parent enthusiastically exclaimed, "You'll fit in around here if you play guitar!"

Whanau and whanagatanga are a central part to Ngāti Pōneke's Club nights. Parents talk quietly to each other as about thirty junior members line up in their rows ready for kapa haka practice. For every child there is an equal amount of parents; some of whom are nursing babies. A small number of older members congregate in the corner and a few toddlers roam around in the whare tapere next to the dinning area. A table in the corner is stationed for members and visitors to give koha. The tamariki enthusiastically stand in line and wait to give the receptionist their gold coin donation. In the other corner, there are signs of the Club's proud history with newspaper clippings draped on the wall displaying their various media spotlights and competition wins.

Michael Preist, the lead guitarist, invited me to play guitar with him during the practice, an offer that I eagerly accepted. After an initial hymn and karakia, I stood behind the group and followed Michaels lead. This proved difficult as I needed to interpret his left handed guitar fingering, while also trying to learn the song structures. The energy of the junior group was high and their voices loud, which made it difficult to hear my own playing. After a few waiata I decided to put my guitar down and observed the practice from the side of the room.

There are usually two members of the senior group that run the junior practice and they will rotate weekly depending availability. One kaiako will stand at the front and demonstrate the actions, while another will maneuver themselves around the children and assist those who are having difficulty. Some parents choose to lineup at the back and perform with the juniors, while others are happy to talk with friends and family about their events of the weekend. I joined in at the back of the group with the parents. The approach that is taken 
to the junior practice is relaxed and informal. Accordingly, I felt at ease that my participation would not disrupt the practice. My lack of in-depth experience is obvious, but the kaiako and parents around me were encouraging and kindly correct me if what I was doing was incorrect. If a new piece is taught, the kaiako separates the boys and girls to learn different gendered actions. This occurs if the girls are being taught to poi, or the boys are learning a haka. At the end of the practice, girls will perform what they have learnt to the girls and visa-versa. The junior practice will finish with pānui and then a small supper before the beginning of the senior practice.

My first visit to Ngāti Pōneke seemed typical of all visitors that come to Club night. New visitors frequent Pipitea and they are always warmly welcomed with an introduction to all the present members at the conclusion of the junior's practice. Membership is not restricted to Māori and many non-Māori attend regularly. In some cases parents will encourage their tamariki to join the junior group, but choose not to participate themselves. They are content to observe and be part of the Ngāti Pōneke community. Commenting on why parents encourage their children to participate, one member of the parents committee, Trish Beamsley states:

They're there for the whakāwhānuangātanga, they're there for learning the waiata and learning the poi...you are there to learn more about your culture, for example tikanga. Tikanga is very much a part of being at Ngāti Pōneke. That's why we have karakia, thats why we learn waiata and that's the whole reason we have supper. Strictly speaking we are tapu when we are learning and doing our thing and then to whakanoa the kids we give them something to eat and something to drink, which means they are then free to go out into the world and live their lives until next Monday to do their learning...it's a house of learning. (personal communication, June 2014)

Ngāti Pōneke Young Māori Club recognises tikanga. Correct procedure and custom is held in high regard at Pipitea marae and is incorporated into rehearsals. Tamariki "are there to learn more about their culture," through experiencing and participating in tikanga and marae protocol. Ngāti Pōneke provides mātua and tamariki a time and place to engage with "waiata and poi," but also experience Māori ways of “do[ing] our thing." The weekly rehearsals are conducive to building whānuangātanga as Pipitea is a space where like-minded people come to share in the experience of performing.

Attendees of Ngāti Pōneke are at different stages of their engagement with te ao Māori and attend Pipitea for a number of reasons. In my case, Ngāti Pōneke is a point of access to experience and learn about Māori practices through the performing arts. For others Ngāti Pōneke provides a space for Māori to be Māori, to learn waiata and to be part of an active performing group in the community. In this sense, Pipitea marae is both a whare tapare and wānaga. The belonging and affinity that draws people to Ngāiti Pōneke is born out of the 
clubs unique history and reputation as an urban kapa haka group, a history that deserves further explanation.

\section{Genesis of Ngāti Pōneke and Pipitea Marae}

The genesis of Ngāti Pōneke Young Māori Club is cemented in the first wave of Māori urban migration in the early twentieth century. The Great Depression, while having a large economic effect on all of Aotearoa, took a particularly heavy toll on rural Māori communities (Peters \& Andersen, 2013, 306). With rural communities unable to support an increasing population and growing labour force, many Māori searched for work in Wellington. According to 1945 census data, in the year 1936, the total population of Māori living in Wellington City was just 337 (Grace, 2001). There were settlements of Ngāti Toa and Te Āti Awa in greater Wellington when The Treaty of Waiatangi was signed in 1840, however, Wellington had not seen an incoming migration of this extent before (1929, Whitcombe and Tombs).

With the influx of Māori migration to Wellington, the 1930s saw church and welfare groups realise the importance of sustaining Māori identity and cultural connection. One such church group, the Māori Mission Society, was established to support, encourage and arrange sport and social events amongst young people. This idea was expanded by Lady Pomare and her Māori Women's Welfare Committee, and in 1937, the Ngāti Pōneke Young Māori Club was formally established with the help of Sir Âpirana Ngata, a politician, scholar and composer. The name "Ngāti Pōneke" is a Māori translation of Port Nicholson (Wellington Harbour) and was gifted to the club by Ngata. A smaller "young club" was formed to help younger members with their musicianship and singing. Membership increased, the singing improved, and all attempts to drop the 'young' label where dismissed as "this was a club for young people (Grace, 2001, 84).”

\section{Ngāti Pōneke: a Place of Belonging}

In The Silent Migration, an oral history of Ngāti Pōneke's inception, early members recall their experiences while being part of the Club (Grace et al. 2001). A common theme emerges amongst the narratives of early members; that of young lives in cultural transition (2001). For 
members, it was a place that provided a support for people who had migrated to Wellington, while also encouraging the continuation and teaching of Māori culture and heritage (79). Many attended Ngāti Pōneke for fellowship and whanaungatanga. One early member, Vera Morgan, described it as a "home away from home," while she was isolated from her friends and whanau. Another member, Mihipeka Edwards describes Ngāti Pōneke as a place of belonging:

I will always be Ngāti Pōneke until I die. I owe the club so much- for its protection; for the joyous things we did together; and for the warmth I never got anywhere else. We hung onto each other. It was our whānua. Ngāti Pōneke was our tūrangawaewae, our rock and strength, our protection. Without it we would have gone around like people with no heads. We'd have been lost. At Ngāti Pōneke I could stop pretending. $(2001,90)$

Ngāti Pōneke, at this time, was not only a Māori performing arts group, but a community that relieved feelings of dislocation and loneliness, all during a time when friends and family were leaving home to fight in a Pākehā war. But stories of pride, joy and excitement override these moments of sadness, to a common feeling of belonging and cultural survival.

The formation of the Club is also seen as wider effort by Appirana Ngata and other leaders to energise Māori and create a presence in the national conscience. They saw initiatives like NPYMC as ways to ensure cultural transmission to younger people who were away from their tribal bases. This was during a time when colonialism was swiftly assimilating Māori into Pākehā society, propelled by loss of land, loss of tribal authority and sweeping bans on speaking te reo in schools (Brown, 2012, 225). Sir Āpirana Ngata is widely regarded as the "father of action song" (McLean, 1996, 337), and as someone who played a large role in inventing the modern genre (1996). Ngata popularised the waiata-a-ringa during the First World War by featuring them in concerts he organised around Aotearoa for the Māori Soldiers' Fund.

\section{Ngāti Pōneke in the Present-day}

Ngāti Pōneke is one of the first pan-Māori groups to declare themselves an iwi, simply by calling themselves Ngāti Pōneke (Mead, 2003, 225). Ngāti Pōneke associates itself with Pipitea marae, an urban marae whose tangata whenua is Te Āti Awa. Pipitea marae was built in 1980 below the old Pipitea pā and was designed to cater for the growing Māori population in the Wellington area. The Ngāti Pōneke Club were involved in fundraising for the project and today much of the club's resilience is attributed to having a marae space to practice. 
Ngāti Pōneke regularly entertain in the community and compete in national and regional kapa haka competitions. The first months that I attended Pipitea, the group was rigorously practicing for the Wellington regional hapa haka competition. A heavy practice schedule was employed with noho at Pipitea marae to accommodate weekend practices. There is an influx of new members leading up to times of competition with many people in the community aware of the Club's inclusive "open door" policy; many of whom will discontinue their participation if the group fails to progress to the next competition phase. This irritates some of the more long-standing members for various reason, but other members are comfortable having the extra bodies on stage to help them perform. It is a polarising issue, especially with the senior members, and is often a topic of debate when discussing the future of Ngāti Pōneke (as I discuss in Chapter 4).

At the conclusion of my first Ngāti Pōneke Club night, we gathered in a large circle, locked arms, and sang our last hymn and karakia. I was warmly invited to attend the following week and encouraged to bring friends along to share the experience. I did not attend Ngāti Pōneke that first night with the predetermined notion of including the Club in a Master's project the following year. It was after several weeks of attending practices and familiarising myself with the waiata that I began to question the larger benefits that learning Māori performing arts might have on someone like me who wants to engage with Māori culture. Attending Pipitea also reinvigorated my aspiration to learn Māori performing arts, something that was instilled during TeUrekore's course in previously. It became apparent that NPYMC is more than a performance group. It is a place that members identify as home, a space for family and friends to stay connected, and a whare wānanga for knowledge to be passed to tamariki. At the centre of the club is music and I found it fascinating how Māori performing arts was used to marry these facets together. I contacted Tamihana Katene to see whether he was interested in collaborating on a research project into how Māori performing arts can be used as a medium to experience the Māori world and connect to Māori community. What interests us is how Māori performing arts can be utilised to transfer knowledge to the younger members of Ngāti Pōneke as well as the students that he teaches at NZSM. In February 2014, I joined Ngāti Pōneke as a registered member and have been attending Monday night rehearsals for eighteen months assisting with guitar and learning while I stand in line. 


\section{Chapter 3}

\section{Learning Through Māori}

\section{Performing Arts}

Māori performing arts communicates knowledge, culturural practices, language and custom. In this chapter I explore how this is achieved in an urban kapa haka group setting and a tertiary institution music performance course. Through methods of participant observation and interviews this chapter demonstrates how the performing arts provides Māori and nonMāori an opportunity to access culture and community. Below I begin with an extended ethnographic section of my experiences before investigating how language and cultural values are learnt through immersion in Māori performing arts (Vygotsky, 1978).

\section{The Ngāti Pōneke Young Māori Club}

August 10, 2014

I arrive early at Pipitea marae to help setup the whare tapere. Expecting an audience of 200, some of us set up chairs while others practice poi and warm up their voices by the elevated stage at the front of the whare. Tamariki can be heard playing in the distance in front of the whare tapere while in the kitchen, the clanking of dishes accompany friendly chitter-chatter while wahine prepare kai for afternoon tea. Ngāti Pōneke Young Māori Club is hosting a kapa haka event to raise funds for the Club to travel to Turangawaewae in two weeks time, to perform at the Kingitanga celebration. Primary and intermediate school kapa haka groups from the Wellington region are invited to Pipitea to perform and whakawhanuangatanga at an afternoon performance and kai. 
All senior members and tamariki are instructed to go to the front of the whare and prepare to pōwhiri their guests on to the marae. This includes me, as a member of the weekly senior kapa haka group. After some encouragement from Mike and Eugene, and some reassurance that I am indeed part of the club, I line up with the group on the steps of the marae. Until this point in my life, my involvement in pōwhiri has been the role of manuhiri. Today is a different and unnerving experience as I am part of the group performing and welcoming guests on to Pipitea marae; there is a sense that I should be knowledgable as it is the tangata whenua that leads pōwhiri.

I stay at the back of the group as we split into four lines. In between every senior member is a junior member, ready, waiting and excited to play their part in the welcoming ceremony. We wait for all the groups to gather at the marae entrance. While waiting, three young men pass around a pütätara, each trying with varying levels of success to produce a sustained sound.

With the elders in position, seated on the right of the marae, one senior member of Ngāti Pōneke consults with the manuhiri at the gate. Not being able to see the marae entrance from where we are standing, I am unsure of how many guests we are welcoming on, but gathering from the amount of seats set on the left side of the marae, we are expecting a considerably large group. I wait with nervous excitement. Not only am I going to experience pōwhiri that observes formal marae protocol, but I will also have the opportunity to perform, as part of pōwhiri, with Ngāti Pōneke. The Club's inclusive ethos gives me an advantage, as both researcher and performer, to be part of pōwhiri performance within the group. I am able to experience proper marae protocol as a both a performer and member of Ngāti Pōneke, an opportunity that is not usually afford to nonMāori.

Eugene liaises between the tangata whenua and the manuhiri to discuss the process of the pōwhiri. Upon giving the signal, a woman to my left begins to karanga. We stand together as a group, arms lengths apart, and wiri while karanga continues. The manuhiri slowly walked up the sloped path and come into our view as they step around the corner and into our view. The child in front of me shuffles from side to side to try to sneak a peak at all the people who are walking on to 
their marae. "Pssst, oi. Wiri!" one senior member sternly reminds their tamariki. This is a serious and formal occasion and sometimes tamariki need to be reminded.

After the karanga is returned by the manuhiri, Ngāti Pōneke launch into Tōia Mai Te Waka. "Ā, tôia mai," the leader shouts at the top of his voice with a supportive "te waka!" chanted in unison by the rest of the group. While watching our haka pōwhiri, the guests move slowly from the centre of the courtyard to their seats on the left. The sound of thirty men, woman and children chanting in unison echoes off the apartment and office buildings that surround the urban Pipitea marae. We stop performing when the guests reach their seats.

A Ngāti Pōneke kaumātua stands and takes a few steps towards the manuhiri. He recites korero for some time, supporting his words with hand gestures and speaking in meaningful and considered fashion. His korero is interrupted by an ambulance that screams down Thorndon Quay, which serves as another reminder of the cityscape that surrounds us. When he concludes, Ngāti Pōneke as a group sing a waiata to support the whaikorero of kaumātua. I move inside to get ready for our performance while the older members hongi the manihuri before they enter. This performance is an important one for Ngāti Pōneke. It will be our last "practice" performance before we travel to Tūrangawaewae.

\section{Learning Te Reo Through Experience}

At Pipitea marae, Māori performing arts is learnt in unison through a process of observation and imitation. For example, Ngāti Pōneke will sing a waiata once through, then, those that recognise the song take the lead and continue to sing until others become familiar with it. The waiata is repeated a number of times, and if need be, the kaioko will pick out particular lines that need extra work. Learning by imitation provides access to language, however, in previous years a more focussed approach to te reo learning was incorporated into weekly rehearsals.

During my presence at Ngāti Pōneke Club nights, a combination of te reo and English is spoken on club night. For the most part, the junior and senior groups are given specific directions in English. For example, the kiako usually gives musical direction and advice on specific parts of the a waiata or haka performance, but will still use Māori performing arts terms such as rangi when talking about the melody or mita when discussing 
the rhythm of a haka. A majority of the time, however, specific direction on the musical elements of waiata and haka are not needed as the songs are usually learnt with an observation then imitation approach.

The amount of te reo that can be learnt on club nights is dependent on two factors: the kaiako's knowledge of the language (see chapter 4), and the extent to which the individual chooses to engage with the material at club night. An example of this is seen in the experiences of Eugene Ryder during his first years at the club. I asked Ryder whether he found club night to be helpful in gaining an understanding of te reo when he first started attending club night:

Well, actually I was quite challenging for the leader at the time who was Pakea Winiata...I would challenge everything he said and did and it wasn't until he left that I realised most of what I learnt, I learnt from him, and if I'd only paid more attention rather than challenging I would have learnt a lot more. So yea, it didn't happen straight away and I continue to learn off others that are there and people external to Ngāti Pōneke. (E. Ryder, Personal Communication, July 27, 2014)

Eugene's experience demonstrates how an individuals commitment and engagement with club nights directly affects how much can be learnt. Ryder has found attending club nights to help acquire elements of Māori language, but regards his earlier experiences of not paying attention as a missed opportunity. As Ryder explains, the kaiako at that time taught in a unique way that helped Eugene learn:

An example was, he'd [Pakea Winiata] teach us a haka and we would learn it in the dark and we would go over it and over it and over it until we had basically memorised it and then he'll break it into different parts, he'll break the men into different groups and say to one group- this is your part, go away, find out what it means come back with the actions- it was that kind of stuff, because he wanted our actions to reflect the words. Rather than us memorsing the words and actions, we had to understand what the words meant and create the actions and by doing that we were learning what the words meant. (E. Ryder, Personal Communication, July 27, 2014)

Ryder adopted a similar teaching process at a practice this year when he taught the senior group a new waiata. With the words up on the wall for us to see, we sang through the new waiata a number of times and familiarised ourselves with the words. He then instructed us to break up into three small groups and create actions to accompany the words. ${ }^{13}$ There is a variety of te reo ability at Ngāti Pōneke and it is not essential for members to be able to speak Māori language during club nights as English is the primary language spoken. However, this exercise required those with more knowledge to assist those who are not as fluent.

For this exercise I was assigned to a group of six members to work collectively to translate te reo, by way of a quick translation to English, into an appropriate action. Myself and others who where inexperienced in te reo were able to learn from those who were more

\footnotetext{
13 When performing waiata-a-a-ringa, the actions reflect and reinforce the poetry of the words, thus, having some knowledge of te reo was beneficial in order for each group to assign the appropriate action to each phrase
} 
knowledgable. Line by line we interpreted the meaning of each phrase or word. After discussing as a group, we assigned an action that properly reflects what is being conveyed. For example, a line would mention the word aroha, which for all of us was immediately recognisble as meaning 'love' in English. The task was to now discuss how this could be best represented through the physical movements of our arms and body. The most obvious movement for aroha is to draw attention to your heart by folding your right arm over towards your left shoulder while continuing to wiri, then gently moving your arm to the front of your body and then back to your side. This was our group's interpretation of aroha, and while the two other groups choose to draw attention to the heart, this was done in a variety of ways. Some words and phrases were recognisable from other waiata that Ngāti Pōneke sing and therefor easily transferable to the actions that we were creating. We completed the waiata and by the end of practice we had three different interpretations of the waiata-a-aringa.

This exercise fused the corporeal movements of Māori performing arts with knowledge embedded within the language of waiata. It helped us learn and remember te reo phrases by associating the physical movements with individual terms; it brings the 'doing' of Māori performing arts together with the knowledge that creates an informed performance. I expressed to Ryder my positive experiences of that practice and he agreed that it is a procedure that they could maybe adopt more often:

It's maybe something that we can pick up on and maybe go over all of our songs again, because a lot of the old song, we don't know why those words are those words and why those actions are those actions. There were times when I was singing songs from Ngāti Pōneke for about ten years and when I saw it written I realised I was singing the wrong words, it was crazy. It was the way it was. (E. Ryder, Personal Communication, July 27, 2014)

Ryder notes that it is a worthy procedure to adopt, because without it, some members may be inadvertently reciting the wrong words. But while singing the wrong words is an issue, as I discuss in the following chapter, people are not necessarily drawn to Ngāti Pōneke Young Māori Club for educational purposes. Accordingly, I asked Ryder whether members feel there is a necessity to understand the knowledge within waiata they sing, he replied:

I'm not sure that its a need- people learn the songs because we're singing them, its only this year and probably last year that we've started putting words up- we used to just sing the songs and people would pick them up, but people would pick up what they perceived the words to be and thats where we realised that maybe we should start putting some words up. And even that was difficult because we didn't know what the words were and we had to go to the older members and find out what they were, then we found they were totally different words from what we were singing. (E. Ryder, Personal Communication, July 27, 2014)

There is a need to for Ngāti Pōneke to cater to those who attend weekly Pipitea marae rehearsals to exclusively perform. However, as Ryder notes, this has resulted in the wrong words being sung. 


\section{Ngāti Pōneke Club Night is an Opportunity}

While some members attend to engage with language, most members attend club for a variety of reasons. Monday rehearsals provide members with an 'opportunity' to engage with Māori knowledge and culture, which can be achieved in a variety of ways:

I think its your own personal motivation, ya'know if you want to come and memorise songs, you can do that, but if you want to come and understand songs then there is an opportunity to do that as well, whether you learn to understand those things within Ngāti Pōneke or not is up to you, we have the capacity in Ngāti Pōneke to teach what each song means and we know that when we are introducing songs we are also introducing the meaning of those songs... (E. Ryder, Personal Communication, July 27, 2014)

Members attend Monday night rehearsals for a variety of motivations. In my experience, the Ngāti Pōneke Club provides access for people wanting to engage with the Māori world outside of a formal classroom environment. Whether its by way of learning te reo through waiata, or being involved in kawa protocol, there is an opportunity to be part of an informed community. Eugene labels the Māori performing arts contingent of Ngāti Pōneke as a starting point for learning, all of which is determined by the individual:

...[W]e don't say, okay today we are going to learn this, or we are going to learn to say this or that, I think it's down to personal preference. I see Ngāti Pōneke as an awesome stepping stone for going on to more constructive ways of learning, whether it is reo classes or education and stuff. (E. Ryder, Personal Communication, July 27, 2014)

Personal preference and motivation is the principle the senior members adhere to during their rehearsals. A "stepping stone" is the implicit assumption that members attend Ngāti Pōneke with, especially at senior level. The junior group, however, has a learning focus to their rehearsals as they are naturally less experienced and have more to learn.

\section{Tamariki Immersion}

Practice begins for the junior group at $6 \mathrm{pm}$, or once a majority of the parents arrive with their tamariki after their work commitments. Practices begin with a warm-up song and parents are encouraged to join in at the back and either aid the kaiako or learn how to perform. Towards the middle of the rehearsal the group breaks in two and the boys practice haka while the girls rehearse poi. When new waiata and haka are taught, there is an element of learning, but there needs to be an element of fun to keep them engaged:

we talk to them about why they are doing what they are doing, what it means, and for kids that age our understanding is there has to be an aspect of fun in it- so they're not keen on just sitting down and listening to stories. We do a bit of role playing with them and show them why the poi 
is done this way. Some of the stuff we do has the meaning behind some of the kupu and some of the songs we're doing for an adult mind and so we don't delve into the details why certain songs are done certain ways, but yeah we add an aspect of fun to it. (E. Ryder, Personal Communication, July 27, 2014)

Tamariki are provided with an environment every Monday where they can learn through performance of waiata and haka. However, engagement is not solely left to waiata performance and te reo knowledge is imparted whenever possible. For example, on one occasion, to subdue an energetic group of boys at haka practice, the kaiako introduced a game of "simon says" with te reo verbs; this was meet with a favourable response from the tamariki.

In Ryder's experience, te reo is best learnt in an immersion environment, which Ngāti Pōneke is able to foster. Language acquisition is the "unconscious process that occurs when language is used in real conversation" (Mihaka, 2008, 1) and occurs throughout junior practices. At the conclusion of junior practice there is panui, which gives anybody the opportunity to address the club and something that is usually done by parent committee members. Some choose to address the group in te reo, but those that korero in English regularly use reo terms and phrases. These are meaningful interactions between pakeke and tamariki, with the expectation that the interaction will be reversed (Royal-Tangaere, 1997).

Immersion at Ngāti Pōneke also encompasses involvement with manakitanga, whanaungatanga and tikanga. In a study of language development of Samoan children, Elinor Ochs (1986, cited in Royal-Tangaere, 1997) found that when children learn language within a particular cultural setting they also learn to socialise, that is, learn the ability to act appropriately within the cultural context. While language gives children the ability to socialise, it causes the child to internalise the values of that culture (Vygotsky, 1978). "The only reason we wont have a standard practice," Trish explained to me, "is for kawe mate...but usually, everyone gets involved everyone turns up and do what ever we need to do, whether its a pōwhiri, a whakatau whatever it is." I recall attending a club night when Ngāti Pōneke needed to pōwhiri a group of manuhiri onto the marae. I was given the opportunity to support the kaumātua and aid Ngāti Pōneke in the welcoming process. By performing, I learnt correct pōwhiri procedure by recognising patterns of interaction, which require appropriate behavior (Royal-Tangaere, 1997). Tamariki learn in a similar manner through recognising both verbal and nonverbal interactions which drive the pōwhiri. Language is the tool that drives the pōwhiri interaction and with repetition and prompting, the process can help tamariki internalise cultural values such as tapu, as Royal-Tangaere explains:

The young child learns the many facets of tapu depending upon the context, the social interaction within that context, and the language used. These rules often occur in the shape of routines and recognised patterns of behaviour within those culturally structured activities. The activities provide culturally specific forms of teaching $(1997,54)$. 
Simply negotiating social and cultural interactions has many educational benefits for tamariki who attend Ngāti Pōneke.

\title{
Voices: Non-Māori Experiences at Ngāti Pōneke
}

The immersion approach is not only valuable for tamariki at Ngāti Pōneke, but also many non-Māori guests that attend on a regular basis. I have already discussed my own experiences of acquiring knowledge as a non-Māori participant, but because of Ngāti Pōneke's 'open door' policy, many other non-Māori guests also attend club nights. The following interview transcripts are with Teng Zhang, the Ngāti Pōneke photographer who only recently moved to New Zealand from China, and Raquel Saenz who has lived in New Zealand for five years:

\section{Me: Have you found while doing (your photography), that you've been able to learn cultural background etc?}

\begin{abstract}
Yes, very much, a lot of culture and how you do things. When you first come (to New Zealand) you only see the front of the culture, you can't get in too deep...[For example], they have very strict rules for entering the marae. Even if you're taking photos or video it's best not to cross the room from left hand side to right hand side or vise versa because of something about the host and the guest. So if you do need to take photo or video its best to stay at one side...It's very good for me because now I know what to do in these situations.
\end{abstract}

...I learn through doing, and sometimes...if I don't need to take photos I usually just do the performance. I learnt one Māori song while I was a student in language school studying english and then I went to the marae and they were singing the same song, but they had dancing with it.

\section{Me: was [performing] hard to get into it when you first started going along?}

Yeah...I'm a foreigner and non-Māori...In the beginning it is quite difficult to get into it...but you need to have a try and trust yourself. They are very welcoming and can help you with stuff. Sometimes if you don't understand just ask them and they'll tell you how to do it.

(T. Zhang, personal communication, June 30, 2014)

Ngāti Pōneke's manaakitanga and open door policy allowed Zhang to forgo any reservations he may have had about performing with the Club. As the Club photographer, Zhang takes videos and photographs during rehearsals and performances. By attending rehearsals he is able to experience more than the "front of the culture" by being part of an informed community. Involving himself, with the guidance of Ngāti Pōneke members, has helped Zhang become educated in kawa protocol. Now he has "trust" in himself to act appropriately in a variety of formal marae situations. Similarly, Teng "trusts" himself with performance of Māori arts; if not required to film, Zhang involves himself in the rehearsals, or will sit and observe with the other non-participating members. Zhang has joined an informed community of Māori 
performing arts at Ngāti Pōneke when he recalls recognising a waiata being performed at Pipitea that he had learnt at an induction day for international students at Victoria University the previous year. The familiarity of the waiata and the shared comradeship that comes with musical performance allowed Zhang to access the performance community at Ngāti Pōneke and further his comprehension of Māori performing arts by learning the accompanying actions.

Raquel Saenz has been attending club for the same amount of time as Zhang and has reinforced what she learnt through formal wānanga classes:

\section{Me: Have you learnt anything as an offshoot to learning kapa haka?}

It's just [the] setting because we do it in a marae. I knew the rules and everything because when I did my course we'd do noho marae, you learn certain rules, certain aspects of the culture that you maybe can't learn in a class...I suppose I have, its reinforced the waiata that I knew (and I've learnt) new waiata.

I wouldn't perform on my own, I don't know it so well that I can pull it out, but with a group its fine because you are supporting each other.

...Sometimes in the past, like the other day when we had the matariki movie, in the past not only have we done the waiata and practiced kapa haka- one day they talked about wheke and they explored how Pōneke came to be Pōneke, or how they discovered Wellington. Sometimes they do extra, but sometimes they don't and I like it when they do those extra bits. (R. Saenz, personal communication, July 16, 2014)

Saenz attends Club with her four year old daughter and can be seen assisting her with actions and words throughout the practice. For Raquel, attending Ngāti Pōneke is akin to entering a place of knowledge where she can learn aspects of Māori culture that are unattainable in a classroom, or at least, the marae is able reinforce aspects of her classroom education (i.e pōwhiri process). Saenz recognises Māori performing arts as a safe gateway to Māori culture for her because it is performed with the support of knowledgable members. Not only is support rendered during physical performance, but also in the strength that underpins Ngāti Pōneke's long term goal to educate their tamariki and anyone in the wider community that is interested in Māori culture. Raquel mentions her fulfillment of learning "extra" excerpts of information and gives the example of when the junior practice finished early and a DVD regarding matariki was shown to the tamariki and parents. This action was taken when some members of the parents committee were made aware that some juniors were not informed of the knowledge and stories woven within the traditional seasonal meaning of matariki. Saenz learns these "extra bits" by way of having new waiata explained during rehearsals, and engaging with Ngāti Pōneke's educational excursions. Raquel attends Ngāti Pōneke because 
she enjoys the affinity of performing in collaboration with highly skilled performers, which grants her an opportunity to be part of the Ngāti Pōneke Young Māori Club community.

The unification of performance speaks symbolically to the common goal of shared community interested in the transmission of Māori knowledge. Learning and performing waiata provides Ngāti Pōneke members with a space and an opportunity to engage with Ngāti Pōneketanga and Māori ways of being and doing. The waiata that are sung are specific to Ngāti Pōneke, and discuss the experiences of Māori in Wellington that unifies the Ngāti Pōneke community, while learning te reo and carrying out tikanga connects to a broader Māori identity and community. 


\section{Te Kōkī Māori Performing}

Arts Course

The Introduction to Māori Performing Arts Course at Te Kōki New Zealand School of Music not only exposed students to a variety of Māori music style, but also motivated students to engage with Māori culture, knowledge, language and custom. TeUrikore Biddle, the teacher of the course I completed in 2010, emphasised the importance of acquiring a holistic understanding of Māori culture while learning waiata, haka and mōteatea. The course required students to learn the significance of Māori performance practice, and especially for traditional laments (mōteatea), the cultural context in which they were performed. While the course was focused on Māori music performance, it was made clear in the first lecture that students will need to gain an understanding of Māori cultural practices to pass the practical assessment and course. The assessment schedule and requirements for the practicums were as follows:

- Composition- The organisation and arrangement of sounds, words are correct - I whakahua tika i ngā kupu

- Questions - Group demonstrates an understanding of the protocols associated with the practice of traditional laments and has a sound understanding of the history, significance, genre or composer of the song - E mōhio ana te tauira ki ngā āhuatanga katoa o te waiata i whakamātauhia.

- Accent - Where appropriate emphasis of body movements is used eg. Pukana, elaborative extension of actions - Kei te tika te whakamahi i te pūkana, te kori o te tinana

- Unity - The group form is a harmonious whole - Tū kotahi ai te roopu

- Overall - Performance was well executed - I rongo i te ihi, te wehi, te wana o ngā mahi nei (Biddle, 2010) ${ }^{14}$

As shown by the assessment criteria, students were advised to study Māori performing arts while engaging with the many characteristics that are weaved within performance. The

\footnotetext{
${ }^{14}$ This information is gathered from the lecture slides that were shown to the class in the introductory lecture
} 
community aspect featured strongly in the course with an emphasis placed on collaborating and fostering relationships with peers. Biddle explains:

What I emphasise in my lectures is scaffolding, tuakana teina [older, younger]... I present this idea of whanaungatanga, which is forming positive working relationships with each other, the idea that as a music student they have these set of skills, as a Māori studies student you have these set of skills. Your international students may not necessarily have either of those skills and will always be your teina. But a music student can act as a tuakana in the class even though he or she may not have a strong background in Māori studies. (M. Cross, 2010)

At the beginning of lectures, Biddle told us to whanaungatanga, setting time aside to share ideas, knowledge and strengths, while providing an environment that assured students would respect each others various skill sets. The practice of whanaungatanga acknowledges tikanga Māori.

The structure of the course, the process with which it was taught, and the holistic approach to Māori performing arts follow the model of the tīenga. Raranaga, or the art of Māori weaving, is the model used by ka'ai-Mahuta (2010), that transfers the conceptual map of te ao Māori onto Māori performing arts. Much as te ao Māori exists within a holistic framework, Māori performing arts, as illustrated by the tîenga model below, is most appropriately understood in relation to a holistic understanding of te ao Māori: ${ }^{15}$

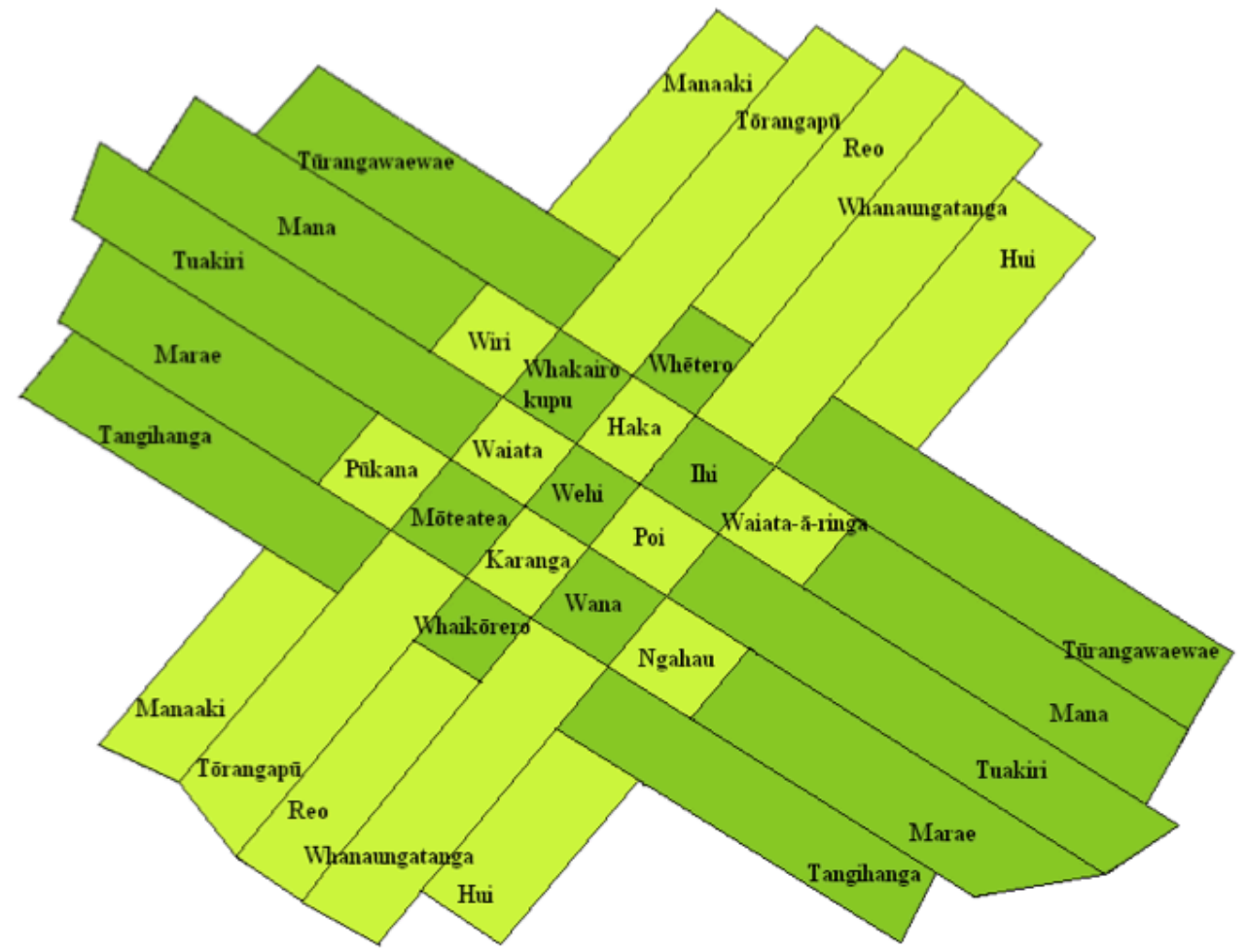

15 The tīenga is a model for both the approach to researching Māori performing arts, as discussed in the introduction, and the process by which Māori performing arts is taught. In this section I refer to the tīenga model as process. 
Ka'ai Mahuta notes how this model is illustrative of the holistic nature of the Māori world-view as it demonstrates how concepts are woven together in the form of a traditional raranga $(20,2010)$. Raranga, the art form, belongs to Te Kete Aronui, which is one of the three baskets of knowledge and is connected to love, peace and the $\operatorname{arts}^{16}(2010)$. As shown in the model, significant concepts are woven together on the periphery pertaining to te ao Māori, which in turn, support and strengthens the Māori performing art concepts in the centre. Whanaungatanga, the idea presented earlier, is just one example of a concept that creates and then reflects Māori performing arts concepts in the centre of the tīenga. These are only just some of the concepts that can be included on this model; with more concepts, comes a larger tīenga and therefor a greater research scope.

The tīenga is helpful in understanding the breadth to which Māori knowledge is taught alongside more specific teachings of Māori performing arts. In the following section I discuss how Māori performing arts is used as a medium for students to access Māori knowledge, culture and language in the PERF 151 introductory course.

\section{Learning Te Reo Māori in PERF 151}

Te reo Māori, which is present on the tīenga, is situated on the weave that also connects whaikorero, karanga, wehi and haka. Te reo is accessible for students with limited knowledge The current PERF 151 course teacher, Tamihana Katene, notes the importance of having a basic of understanding of te reo Māori in the course:

The very first class that I teach in PERF 151 is basic pronunciation, so we go through how to break down Māori words...and piece by piece, how to pronounce each individual component because to me that's key as well, the pronunciation of the words. If you say a word slightly different, it could mean something completely different from the word. So thats been something I've been quite passionate about, getting that right. (T. Katene, Personal Communication, August 27, 2014)

Knowing correct pronunciation and an elementary understanding of te reo is what Katene believes is the important first step that is needed before his students are able to move onto learning Māori performing arts. With a large percentage of international students that make up the class, it is important that everyone has the same base level of te reo knowledge to build on. As shown in chapter 2, Katene insures that all members of the class are pronouncing the language correctly and have a coherent understanding of what they are saying. For example, if

\footnotetext{
${ }^{16}$ It should be noted that not all iwi accede to this philosophy, but this provides a starting point for conceptualising Māori performing arts, its relation to te ao Māori, and the process through which it is taught.
} 
Katene, while discussing the origin of a waiata, were to mention a New Zealand place name, he would invite the class to practice the correct pronunciation through call and response.

This approach to teaching language is 'communicative,' and encourages students to engage with language communication (Nunan, 1991). In recent times, the approach to learning English has become communicative, but as Greensill (2007) points out, in the case of te reo Māōri at tertiary level, teaching still appears to, "either (a) largely focus on clause and sentence level language, or (b) include larger stretches of language without any real attempt to make learners fully aware of the processes involved in understanding and creating them"(3). While PERF 151 is not a comprehensive introduction to te reo, his informal strategy of teaching common phrases and the meanings within these create an environment where students are able to access and communicate in te reo.

It is the participatory performance of Māori performing arts that helps students learn the beginnings of te reo. The combination of learning correct te reo pronunciation with the melody and rhythm of waiata, has helped me become acquainted with Māori language. Most students in the course had at least some experience with music education before enrolling in the class. One student Naomi Morton notes that, "music's always been a really good way for me to learn things" (personal communication, June 5, 2014) and for her, the process of learning through the performing arts gives her access to Māori culture. For another student, Tarryn Harrison, learning te reo through music makes the learning process easier and attainable:

Its easier because most of us would have grown up learning music, so you have that relationship rather than just learning it through speaking it. It's more interesting to learn ... if I'd just gone to a class and just learnt the language I wouldn't have found it as interesting as those songs ... captivated me more. (T. Harrison, personal communication, June 5, 2014)

The familiarity of learning to sing the pitch and rhythm of waiata, provides a comfortable platform to learn the words. Additionally, the physical act of singing helps with the learning process. Unlike regular speech, singing requires a greater connection between the voice and the diaphragm. By default, vowels are pronounced for a longer time and vowel-sound are automatically rounded due to the added air coming from the diaphragm.

Just as waiata are performed in unison, they are also rehearsed and fine-tuned in a similar fashion. The performance aspect of the class is a shared musical experience; the speed with which each waiata is taught is determined by how quickly the class, as a whole, is able to grasp Katene's teachings.

Harrison noted that the most rewarding part of the course for her was learning the language. She continues:

I didn't really know how to pronounce anything. In the first lesson I was a bit overwhelmed with how to pronounce even the vowels and stuff when we first started, but after that, once we'd practiced it I got use to it. (personal communication, June 5, 2014) 
In the first lesson, formal and informal greetings are taught to the class. In my own experience, the initial hurdle to correctly pronouncing te reo is in understanding the use of the macron. ${ }^{17}$ For many, correct pronunciation of ' $a$,' ' $i$ ' and 'o' vowels is the most challenging, as there is a requirement for a more rounded vowel sound compared to typical New Zealand English dialects. ${ }^{18}$ The outcomes of correcting simple pronunciation mistakes are positive as two students explain:

I can start saying Timaru instead of Timaru (Teemaaroo) ... its going to take a few years for me to get the local towns' pronunciation right...it will take awhile, its been nineteen years of saying the wrong thing. (N. Morton, personal communication, June 5, 2014)

(the class is good for learning) place names, I think its good for pronunciation, because I imagine that would really frustrate some people. I mean I do it as well, I say Taamwpoe (Taupō) and Taawronga instead of Tauranga... (T. Dustow, personal communication, May 22, 2014)

Tim, Naomi and Tarryn all recognise the importance of correcting their trained habit of mispronouncing New Zealand place-names. Although a seemingly simple and innocuous task, correct pronunciation affects language pronunciation throughout New Zealand's broader community. There is a flow-on effect where mispronouncing te reo becomes normalised for younger generations and perpetuates the incorrect pronunciation of te reo (Brown, 2006). ${ }^{19}$ This is highlighted by Naomi, who now, after taking the course, has recognised her oversight and is now making a conscious effort to correctly pronounce the name of New Zealand towns with Māori names. The students' new awareness of te reo might be because, for many in the class, the course provided contact time with Katene, a fluent Māori speaker who is someone they would not have encountered while in pre-tertiary education:

\section{Has (learning Māori performing arts) helped as an introduction to learning Māori language?}

Yeah, especially in the beginning. Tamihana mentioned at one point, the class as he knew it was targeted towards international students, so I think last year there was a lot of international students that took this class. At the beginning he...would slip it into class, "oh have you heard

\footnotetext{
${ }^{17}$ When looking at the internal structure of te reo we see a phonological system containing five vowels, each of which can be lengthened with the use of a macron (Kāretu \& Waite, 1987). These vowels are then combined with ten consonance (h, $\mathrm{k}, \mathrm{m}, \mathrm{n}, \mathrm{ng}$, wh, p, r, t, w), which are arranged into syllables of one or two vowels per consonant (1987).

18 A recent study, comparing Māori English and Pākehā English dialects, shows that Māori English is significantly more syllable-timed than Pākehā English (Szakay, 2007). Similarly, Ainsworth's (1993) study of New Zealand radio broadcasters reveal that full vowel sounds were retained $60 \%$ of the time in the Māori sample, while the Pākehā sample were only $20 \%$. This might explain the initial difficulty students have in pronouncing these vowels as there is need to pronounce the vowel sound for a longer period of time.
}

19 Reweti Te Mete, a community language co-ordinator for education agency Te Matahauariki o Tauranga Moana, is advocating for Pākehā, especially those in Tauranga, to learn to pronounce Māori place names correctly. She believes it would contribute, in a large way, to the revitalisation of te reo in Aotearoa (Brown, 2006) 
this word before?" "Do you know what this word means?" slipping in a lot of basic introduction to Māori language. So that helped a lot. (P. Patel, personal communication, June 6, 2014)

Me: Do you think that learning Māori performing arts can be used to gain an elementary understanding in Māori language?

If they did it the way we did it. I mean, we learned a lot about the language at first, but it was kinda unrelated to kapa haka, Tamihana was just slipping it in, like, "oh did you see that sign outside, do you know what that means?", stuff like that. But, it was easier to learn it that way so then you could find connections between words... A lot of times I would see words- and I'm speaking for me and Abbey at least because we are the two international students in the class- in the haka that we recognised from other places, and so we would ask the class, is this a place? is this a name? What does this mean? and so you could learn words easily like that too, but, I don't think it would be a good comprehensive introduction to Māori. (P. Patel, personal communication, June 6, 2014)

\section{Me: Has (doing Māori Performing arts) helped you with language acquisition?}

I think it has a little bit I've had to revise all through my notes before I start speaking, and because it taught in an arty sort of way, its more accessible than like a language course perhaps... I've been thinking about this as well, I've been listening to Ramstein the German band as well, and instead of taking a German language course... I would listen to their songs and pick out certain phrases, learn the words at first, then it becomes something you can sing along to and engage in activley all of the time...learning this sort of style as well, like the mōteatea a find myself singing it sometimes and subconsciously the words get into your head... (M. George, personal communication, June 12, 2014)

Max and Payal note that Māori performing arts makes te reo accessible as they can draw connections between everyday items (i.e. place names) and the words that are sung in waiata. As pointed out to me, this course may not be as comprehensive as a language class, but for the students who are interested in learning Māori performing arts, it provides a base knowledge that they can expand on.

\section{Learning Mātauranga Māori}

So far in this chapter, I have explored the performance of Māori performing arts as a way for students to access te reo Māori through music. This is useful for learning of pronunciation and language comprehension, however, the waiata, mōteatea and haka that Katene chooses to teach also provide access to Māori knowledge. In pre-colonised New Zealand, tangata whenua relied on memory to preserve history. Accordingly, it was necessary to create a means of accessing this history easily; one such way was through the medium of waiata (Ka'ai Mahuta, 2010). Waiata were one of the best ways to retain knowledge as the structure and rhythm 
retained and reinforced the lyrics (2010). This body of knowledge, called Mātauranga Māori, exists today, albeit in a fragmented fashion, as the following working definition outlines:

"Mātauranga Maori" is a modern term for a body of knowledge that was brought to these islands by Polynesian ancestors of present-day Maori. Here this body of knowledge grew according to life in Aotearoa and Te Wai Pounamu. Despite an initial period of change and growth, the arrival of European populations in the 18th, 19th and 20th centuries brought major impacts to the life of this knowledge, endangering it in many and substantial ways. All, however, was not lost as new knowledge was created through the encounter with the European and through the experience of the creation of the new nation called New Zealand. Important fragments and portions-notably the Maori language-remain today. These fragments and portions are catalysing a new creative period in Maori history and culture and in the life of the New Zealand nation. (Royal, 2009, 31 cited in; Royal, 2012)

It is a body of knowledge with Polynesian origins that has regenerated since colonisation in Aotearoa. Mātauranga Māori refers to a 'traditional' body of knowledge, but the term itself is newly conceived (Royal, 2007). Mātauranga Māori, in its contemporary understanding assumes that there is something distinctive and valuable about the Māori world (2012). It is used to describe both the uses and applications of knowledge, as well as the type of knowledge it is referring to. ${ }^{20}$

While waiata is able to retain this body of knowledge, it is also a means to access it. In the context of the course, Katene describes waiata as being similar to what we might consider encyclopedias to be today:

the thing you have to remember about the old mōteatea, the waiata koroua, the traditional chants is that they were carriers for knowledge, thats why they were so long because people would compose these waiata to teach people about certain events, to teach people about certain history, genealogy, lots of things. (T. Katene, Personal Communication, August 27, 2014)

It was the traditional performing arts styles, haka and mōteatea that featured strongly in the class. Many of the traditional chants contain a great deal of historical information as they were usually composed after a significant event, whether it was personal, or an event that was meaningful to a whole community (Royal, 2009). Royal continues that the value of learning mōteatea is that they express a very specific view of Māori experience:

They rise from and express the passion of our people - their trials and tribulations, their dreams and their failures. They may contain subtle comment on the nature of our lives, and they may also contain bold assertions of identity, extolling young people to a larger experience and dimension of life $(2009,5)$.

This sentiment is also expressed by Katene who notes how the performance of Māori arts is reliant on an understanding of the Māori knowledge that Royal discusses:

When you are performing something, you have to know what you're talking about because with our haka with our waiata, they're not just words, its an expression of an ideals, expression of a

\footnotetext{
${ }^{20}$ For example, Mātauranga could be used to aid navigation, while also to refer to the type of knowledge it is i.e implied or explicit knowledge.
} 
thought, of a kaupapa. Without the meaning, whats the point in having the words. (T. Katene, Personal Communication, August 27, 2014)

Two traditional chants were taught in PERF 151; Ka Mate, a haka composed by Te Rauparaha, and Töia Mai Ra, a waiata tangi ${ }^{21}$ composed by Te Rangihaeata. Toia Mai Ra is a lament written for Te Rauparaha, Te Rangihaeata's uncle, who was arrested at the instruction of Governor Grey in 1846 (Oliver, 2012). As shown in chapter 2 with Ka Mate, Katene would describe, in great detail, the context of each of the pieces the students were to perform. On occasion, Katene would informally quiz the class on certain waiata phrases and expect us to situate the piece historically. In this manner, Māori performing arts enabled students to engage with historical information and events that were important to Katene and Ngāti Toa. Waiata provides a medium of melody and rhythm through which knowledge can be accessed.

\section{Learning and Presentational Performance}

As a 'performance' class, a large portion of the overall academic grade for the course is determined by a performance of repertoire in the final weeks of the term. This year, a weighting of thirty-five percent was placed on the class's performance of Ka Mate. ${ }^{22}$ Accordingly, to receive a high mark for the course, students must strive to perform well, but there are many facets attributed to a "good" performance, some of which are not immediately attainable in an introductory class. ${ }^{23}$ However, as two students describe their experiences learning Ka Mate, having a solid grounding in the haka's cultural context and understanding of the knowledge contained within the pieces is synonymous with performing well:

Learning the words is really important for the performance as well. We could have just said the words and had no concept of what they meant, but knowing what they mean gives the performer that little bit extra too. (N. Morton, personal communication, June 5, 2014)

(Learning the context is) more than helpful, I think is necessary because the haka weren't done purely for entertainment... I think it's really important, you can't do the haka right if you don't know what it means. (P. Patel, personal communication, June 6, 2014)

The end of term performance functions as an incentive for students to engage with mātauranga Māori. Naomi and Payal believe they cannot perform Ka Mate correctly if they have not engaged with the knowledge within the haka. Consequently, students are motivated to engage with mātauranga Māori because this will transform into a better performance.

\footnotetext{
${ }^{22}$ In past years, the final performance has been held at Ngāti Pōneke, however, in 2014 the final performance was held in the recreation room at Victoria University.

${ }^{23}$ Tamihana notes that the level of the class is similar to what one might expect at the junior level at Ngāti Pōneke. As a 'beginner' class, there is leniency on much of the subtle aesthetics of kapa haka that take years to learn.
} 
Engaging with the hakas knowledge also gives students a grounding in the historical content of the piece, which is expressed through performance. Katene notes that when the emotional intention of the piece is understood, that is when "the beauty of Māori performing arts comes out" (Personal communication, 2014). He continues by saying, "when the people performing an item have an emotional attachment to what they are saying, thats when the real performance comes out" (2014). There is a difference between merely reciting the words and understanding the waiata on a deep emotional level. Encouraging students to be conscious of the knowledge in waiata is able to lift the performance standard to a "real performance," and motivate students to develop deeper connections with Māori culture. For example, Tōi Mai $R a$, a lament written for Te Rauparaha's arrest cannot be performed correctly without a grounding in the history of the mōteatea. The performance practicum dimension of the class is paramount to engaging with Māoritanga, it is a manner of "expressing an intimate relationship with the culture." Only until a connection is made with the waiata can it be expressed properly and delivered in the way it was intended. Performance motivates students to garner a relationship with the knowledge and experiences contained within Māori performing arts. Performance acts as an incentive to closely engage with the knowledge contained waiata, which further accelerates students understanding of mātauranga Māori.

This conceptualisation of performance is formulated through Katene's own experiences of Māori performing arts being performed by his elders:

\begin{abstract}
When I think back and I remember my elders before me...there was always, always an emotional attachment that they had and it was obvious in certain songs...[W] hen my grandmother use to perform [laments], the attachment was so intense that she would literally start crying, start wailing while she was performing it and thats exactly what you are trying to capture because the song is talking about a loved one that you've lost, you know, this thing that is so precious to me that my heart is wrenched in two that I've lost you. and its hard to say that with a blank face, but when you understand what its about and you feel the emotion behind the words then you portray the emotion behind the words, only then can you portray the intent behind the piece. (T. Katene, personal communication, August 27, 2014)
\end{abstract}

Mōteatea narrate a particular experience captured by its composer that needs to be embodied by the performer. Similarly, students are motivated to have an emotional connection with the waiata they performed, particularly mōteatea, which contains experiences and history that must be respected by correct performance. 


\section{Metaphorical Language}

Everything within our culture is based around the language, having said that, you don't have to speak the language to understand the values of the culture, but the whole philosophies of the culture are based into how we describe things and how the language is used (Katene, personal Communication, August 27, 2014)

In his discussion of the ability of Māori performing arts to carry knowledge, Royal states that mōteatea are able to "reflect and communicate a particular view of the world. They arise from a particular way of experiencing and explaining life..." By learning mōteatea, students are provided a window into a particular view of the Māori world. TeUrikore Biddle notes that Māori performing arts today "merely echoes and reflects the traditional performances one might have witnessed in the old whare tapere, where waiata and haka were but two of the many elements comprising the rituals of encounter performed in traditional times" (Biddle \& Keenan, 2012, 69).

The way objects and emotions are described in mōteatea reflect the Māori world view. Katene notes that there are two different types of te reo, "there is te reo ōkawa and te reo oppaki. Te reo ôkawa is the formal language used in whaikorero and its highly descriptive, its metaphorical... Then there's oppaki which is the common everyday language." The descriptive language, and the poetic form and structure of mōteatea Tōia Mai R $\bar{a}$ exposes students to a different cultural world view and conceptual map from their own. Dustow notices how their is a considerable difference between English and te reo ōkawa, something which has drawn him to a closer understanding of te ao Māori:

I do notice, they seem to use a lot more metaphorical, like all these things are more poetic in the way they describe things than in English we'd describe them a bit more cold and this is what it is, like more of a fact. Like when he (Tamihana) tells us what certain sentences mean- he translates it directly into English then has to translate that again for you. Because the way we think about things is obviously different, just the whole concept or, when you're trying to generate a concept the way they've described it seems more poetic. (T. Dustow, personal communication, May 22, 2014)

One example of this is the traditional language that is used in the mōteatea Tōia Mai $\operatorname{R} \bar{a}$. The line "moe ana te huia ana te kōtuku," is literally translated "the hui sleep and the kōtuku sings." Until this phrase is situated within its proper cultural context, the metaphorical tone to the piece is not as powerful, nor are the references to historic information as intelligible. Katene discusses the meaning of the specific line of the mōteatea while embedded in its cultural context:

(the line is) talking about the huia which is the most prestigious of all birds, the tail feathers of the huia were reserved for the highest of the high, and so by using that term, "the huia sleeps", 
the most prestigious of everything we know is now sleeping. (T. Katene, personal communication, August 27, 2014)

The "prestigious" bird is in reference to Te Rauparaha, who as Katene describes was his "chief of all chiefs." The second half of that phrase, "tangi ana te kōtuku" within a Ngāti Toa context means the "one that carries our essence after we die to the resting place." Heard and understood in their cultural context, these references are powerful and representative of how many of the traditional mōteatea articulate the subjects they are about.

\section{Māori Performing Arts Provides Access}

Māori performing arts serve as a medium for students who have had limited previous engagement with Māori culture. Learning through the familiarity of music provided for many a window into te ao Māori and Ngāti Toatanga. Most importantly, the introductory course in Māori music performance gave students an appreciation of Māori knowledge, which presented them with the confidence to explore other areas of Māori culture as two students explain:

(Now) I have some sort of inroad into at least asking questions...even though I couldn't speak a word of fluent Māori I at least understand how words are pronounced...and I've had an experience, like sharing things in common with people you know. (so I can say) oh yeah I've done a little bit of Māori, not very much, but at least you can talk about it and learn more about it. (T. Dustow, personal communication, May 22, 2014)

I was a bit nervous coming in, I wasn't sure what the perception would be of someone like me coming in. So I guess now I've got a lot more confidence now about that, I can go ask about stuff and can say, I really want to learn this, this is a genuine me wanting to learn this... (N. Morton, personal communication, June 5, 2014)

Performing and engaging with Māori performing arts has given students Dustow and Morton a foundation of Māori knowledge to expand and develop. Māori performing arts is an experience that for these students is a steping stone to further research into Māori performance; it is a point of access to a world view with which they were not previously familiar. In Katene's view, an introductory course allows students to access Māori culture in a comfortable setting. It is a culturally safe context for students to engage with Māori performing arts and develop confidence to engage with Māori culture in the future. Students were initially apprehensive about engaging with a performing art that for non-Māori New Zealanders is considered Māori owned. However, the course promoted Māori performing arts 
as a practice all New Zealanders can engage with. For example, at the beginning of the course Katene demonstrated on taonga puoro. He says he likes to expose students to traditional instruments often because there is a tapu-like reputation about them. Katene continues:

I'm trying to make puoro accessible...(and) get people using them. As long as they have a basic understanding of how they're supposed to be used then they're free to experiment and shape the way they use them on their own. (T. Katene, personal communication, August 27, 2014)

This example also champions the other content that is taught in the class. Learning Māori performing arts is able to lift the perception that certain knowledge is only accessible by a certain groups of people. Approaching Māori knowledge in this way, especially with the aid of Katene, allows students to perform Māori arts without fear of misrepresenting or misunderstanding cultural practices. 


\section{Chapter 4}

\section{Māori Performing Arts:}

\section{Presentational and}

\section{Participatory Performance}

In Aotearoa New Zealand, Māori performing arts is primarily perceived as an art-form expressed for the purposes of presentational performance. The growing popularity of kapa haka competitions and interest of New Zealand sports teams (i.e. The All Blacks) to perform haka before fixtures has, to some degree, pigeonholed Māori performance art as a rendition of cultural and national identity. Consequently, the value of Māori performing arts as a learning tool is not fully acknowledged in national consciousness. In this chapter, I extrapolate the performative value placed on Māori performing arts by discussing a similar dichotomy that exists at Ngāti Pōneke between performance and learning.

A myriad of opinions are held as to what purpose Māori performing arts can serve the club. In June 2014, I was invited to present an outline of this research proposal to the Club's monthly Parent Committee meeting. While at the meeting, the Committee discussed some of their ideas for the future of the junior Māori performing arts group. An item presented to the committee for discussion was whether the club should perform at the Koroneihana celebration. ${ }^{24}$ The excursion would involve junior, intermediate and senior aged members of Ngāti Pōneke performing together for the first time at Koroneihana. A discussion surrounded whether the juniors were "ready" to perform considering the considerable amount of time that had passed since they performed in front of an audience. Some felt Koroneihana presented Ngāti Pōneke with an opportunity to educate their tamariki about the Māori King Movement, an important part of Aotearoa New Zealand history, while

\footnotetext{
${ }^{24}$ Koroneihana is a week long celebration held at Turangawaewae marae in Ngāruawahia and gives people the opportunity to pay their respects to Kiingi Tuheitia and take part in the various events and celebrations that have been organised, including sporting competitions, kapa haka displays and various expos.
} 
other members were skeptical about performing considering the Club's current low membership; all of which could result in a poor performance in front of king Tuhietia Paki and subsequent loss of mana. ${ }^{25}$

Among the present committee members, all agreed that Koroneihana presented a learning opportunity, but it was the notion of representing Ngāti Pōneke through performance that had some members questioning the merits of the suggestion. All agreed that this particular event was an opportunity for tamariki to engage with te ao Māori and learn about an important part of history, however, there was limited time left to rehearse before the event. The concern was whether this positive learning experience should happen at the expense of a good kapa haka performance.

The discussion surrounding the excursion highlights, in a broader sense, whether Māori performing arts, for the juniors, is primarily a tool for learning or a performance practice. In this chapter, the separation of music as presentational or participatory is unpacked in relation to the Ngāti Pōneke Young Māori Club case study. First, this section builds on the previous chapter and addresses the issues that arise from focusing solely on performance, while also discussing the various structures that need to be in place for an informal learning environment to take place. This chapter discusses the issues that arise and differing perspectives of how Māori performing arts is utilised at Ngāti Pōneke. This case study offers an insight into why Māori performing arts is perceived nationally as a uniquely performance based tool, and why educational advantages are often overlooked.

\section{Presentational and Participatory Performance}

It is necessary at this point, to frame the way in which I am referring to these two terms: presentational and participatory performance. While there are many nuanced meanings of the term performance in musical discourse, in this thesis performance refers to the 'act' of performance in a physical sense. I build on Turino's (2008) concept of presentational performance, which references situations where a group of artist have prepared music for an audience who do not participate in the music making (26).

Presentational performance at Ngāti Pōneke involves the Club performing at kapa haka events in the community and at competitions. For example, community events might include end of term concerts where the junior group performs a showcase to their parents

\footnotetext{
${ }^{25}$ Performance was mandatory for all members of Māori performing arts groups who attended Koroneihana. i.e. there was no option available to attend Koroneihana for the cultural experience without performing some items.
} 
and wider Ngāti Pōneke community. ${ }^{26}$ Performance also includes the process of preparing for a presentational performance, which follows a 'learn-while-doing' approach, where the physical aspects of performing arts are learnt by imitation. This is the type of learning that Rogoff et al. refer to as "intent participation $(2003,176)$ "; a collaborative learning environment that is emphasised and valued in communities, where members learn by observing and participate when they are ready to help in shared endeavors (176). The intent participation learning model is how I interpret my experiences of learning Māori performing arts with Ngāti Pōneke at rehearsals, with the added intention of performing (on stage) with the Club in the future. In this sense, performance of Māori performing arts is the process of learning the actions, melody and words through imitation, with the intent to perform on stage in front of an audience.

Participatory performance occurs when there is no performer-audience boundary, only participants and potential participants. The education that takes place at Ngāti Pōneke (as outlines in Chapter 3) is considered 'informal learning' and occurs within a participatory performance framework where the prime objective is to have a maximum number of participants engaging $(26,2008)$. The term 'informal learning' is in contrast to 'formal learning, or as Rogoff et al. refer to as assembly line instruction, where, "transmission of information from experts, [occurs] outside the context of productive, purposive activity. (2003, 176)" Ellenbogen notes that most definitions of informal learning focus on the structure; in general informal learning is described as "voluntary, open-ended and flexible, and lacking an organized curriculum and structure (Ellenbogen, 2002; cited in Callanan, Cervantes \& Loomis, 2011, 647). Parallels can be drawn between learning at Ngāti Pōneke and learning that occurs at a museum, where informal learning exists at the foreground of the activity, but does not contain the same characteristics as a formal learning institution. Other examples include situations where children learn language, and learn about the mind and emotions from their parents, an effective brand of informal learning that occurs in a natural environment, which is both intensely socially collaborative and embedded in meaningful activity (Callanan et al. 2011, 649). Discussed in Chapter 3, the process of learning about the different aspects of Māori performing arts, and what these mean, fits within the coherent 'informal learning' rubric.

Informal learning occurs on club nights when parents informally quiz tamariki on their te reo knowledge, or when discussing waiata-ā-ringa actions; this occurs in between periods of participatory performance. Marae protocols such as pōwhiri are also experienced

\footnotetext{
${ }^{26}$ This is not to say that this idea of performance is aligned with the enduring musicological perspective that performance is supplementary to the musical text. Rather, as Nicholas Cook states, "music subsists in the collaborative action of people playing and working together, so that performance can be thought of as complex social interactions, and scores as scripting them (Cook, 2014, 3).
} 
through a participatory lens and this is when tikanga is internalised. Learning also occurs when attending events that the Club considers 'education outside of the club' (EOTC) excursions. For Ngāti Pōneke, language revitalisation and teaching about Māoritanga is taught through preservation patterns of intergenerational transmission of te reo (Fishman, 1991, 213). The excursion to Koroneihana was considered by many members to be an important EOTC as it provided juniors an opportunity to immerse themselves in Māori culture and community. The people of Tainui and Tūrangawaewae marae at Ngāruawahia have a reputation for exemplary kawa and tikanga and Ngāti Pōneke regarded the excursion as a worthwhile learning experience.

Māori performing arts challenges Turino's performance binary; the performeraudience distinction at Ngātip Pōneke is fluid, and during a rehearsal the distinction can change a number of times. During presentational performances, audience members often participate from the floor with singing and actions and blur the boundary between artistlistener. Participatory performance is the most malleable and occurs during times of both stage performance and informal learning.

\section{Direction of the Club and Presentational Performance}

The membership of Ngāti Pōneke is often changing, a reality that can push the club in a different direction and determine whether the group will focus on performance or informal learning. In an interview with Eugene Ryder, the Vice President of Ngāti Pōneke's committee, he discussed the recent strategic planning that took place at Pipitea marae which gave members an opportunity to collectively decide on the areas in which the club should focus. Speaking of the current membership and direction of Ngāti Pōneke, Ryder states:

At this stage we've got a lot of people...where education is quite the focus and then we've got people that have been at Ngāti Pōneke for years. We have this kind of challenge around; we can't change whats always been, versus we need to change things to move forward. It's a discussion that's always had...its more like an ongoing debate...but (we have) got to bring it back to lets just do kapa haka and try and educate them through kapa haka so we're trying to mold the two ideas of, do we do education or kapa haka. (We) just try to do them both. (E. Ryder, Personal Communication, July 27, 2014)

It seems that this "on going debate" is dependent on the current membership of the decision makers and, to some extent, the knowledge and ability of those managing the juniors, as to whether there is a concentration on performance or education. "Changing what's always been," is regarding Ngāti Pōneke's well-known reputation for excelling in kapa haka performance, a perception that is grounded in the club's long history of performing for entertainment. But there is also an understanding among committee members that it is 
unfeasible to aspire to go back to the "Glory days," of when the club's membership was thriving and performances in the community were in abundance. During this time, Ngāti Pōneke were one of only a few Māori performing arts groups in Wellington and were often called upon for events and people who were eager to join. Today, other performance groups and opportunities exist that enable people to engage with Māori culture resulting in a recent drop in membership. Consequently, the club has needed to adjust its ethos according to existing members and find a way to attract prospective members.

Many individuals are drawn to Ngāti Pōneke for the sole purpose of presentational performance. These types of experience are highlighted in research conducted by Paenga (2008) that examined the health benefits that participants recorded when engaging with Māori performing arts. In her study, performers reported that they associated their participation in Māori performing arts with greater feelings of wellbeing, whanaungatanga and "construction of a secure Māori identity (viii)," all of which are skills and attributes that are able to transfer into other areas of life. The findings of that study are reflected in my own experiences performing with Ngāti Pōneke. The sheer enjoyment that members receive by performing together is displayed across smiling faces; upon hearing the first introductory strum of the guitar, the tamariki switch from disobeying their parents to performing with rigor and accuracy.

Many members are motivated to regularly attend Club nights to focus purely on presentational performance. For most, Māori performing arts is about singing waiata, whanaungatanga, expression of the self through music, and performing with family and friends. This sentiment is shared by Beamsley. I asked her whether it is possible to learn te reo and other aspects of Māori culture while at Ngāti Pōneke and she made the following point:

There are people there that are native speakers, but they are few and far between. You're dealing with people who are urban Māori, you're dealing with people who aren't there to learn the reo, maybe Pākehā people are, but not the Māori people. They [Māori] are there for the whakawhanuangatanga, they're there for learning the waiata, for learning poi, for learning...

(T. Beamsley, Personal Communication, July 23, 2014)

As Beamsley suggests, some individuals attend rehearsal primarily to learn the performance aspects of Māori performing arts, rather than some of the subsidiary elements like te reo and Māori knowledge. Additionally, experiencing Māori performing arts brings people together and builds relationships through the act of performance. However, having a performance only atmosphere has lead to some issues.

I noticed a large drop in attendance after the first two months I was present. When I first started attending club night at Pipitea marae in 2013, the hall was full of young senior members participating in Māori Performing Arts. Ngāti Pōneke were preparing for the Wellington regional kapa haka competition which was to take place in three months time. As 
usual I was encouraged to participate with the group, but as rehearsals became more rigorous and an emphasis on a polished performance became apparent, I decided to opt out of participating and instead observe. There were thirty people in the group at this time, with about twenty people there to watch the group's weekly progress. As a newcomer, I assumed this was the Club's regular attendance. The week after the regional competition, I was surprised that I was one of only a small group who came to rehearsal. The rise and sudden fall of membership at the club was determined by the Club's participation in competition opportunity, as Ryder discusses:

There is a group of people that only come to Ngāti Pōneke for competitions and we're trying to discourage that, we're trying to encourage participation throughout. But the reality is, people want to be part of the competition and they don't want to be part of the Monday night practices... We don't have the numbers that are needed all the time so we welcome anyone at any time... (E. Ryder, Personal Communication, July 27, 2014)

Ngāti Pōneke's open door policy is taken advantage of near times of competition, which leads to fluctuation of numbers during times of competition. In Ngāti Pōneke's case, it is the performance aspect of Māori performing arts, rather than educational benefits, that entice new members to Monday club nights; young members are attracted to the idea of featuring their talents at competition time. Ngāti Pōneke is welcoming of those who are there to compete. Without new members, Ngāti Pōneke's numbers would be too low to participate in competitions. Jules Forde, a student who has recently joined the senior group at Ngāti Pōneke, has noticed the different views that younger members have of Māori performing arts, stating, "I think for my generation,"

it is a lot more about competition and performing for everyone to see you..they love doing [noncompetitive Māori performing arts too], but they love performing in front of people, they love doing it to win things. but it's always about, how can we be better, how can we be more innovative, how can we...stand out from the rest. (J. Forde, Personal Communication, June 13, 2014)

For younger members, there is an importance placed on competition and for some, competition may be the sole reason to participate in Māori performing arts. Whitinui describes the current popularity of competition amongst young individual today as a new kind of rivalry; competing with iwi on the battlefield has now been replaced by competing on the stage $(2008,6)$. Those that are under the age of thirty, as Forde notes, are usually the individuals who are drawn to Ngāti Pōneke leading up to competition events. These individuals join to compete at the Wellington regional competition with the hope of progressing to the coveted Te Matatini national kapa haka competition. For this reason, Māori performing arts is primarily marketed to New Zealand audiences as a competition event and performance spectacle. 


\section{Issues that Arise due to focus on Presentational Performance}

A conscious focus on a "good" performance can come at the expense of understanding how the knowledge contained within the waiata is weaved within performance. This sentiment is felt by Katene, who in his mid-twenties, realising that Māori performing arts is more than just presentational performance, sought to discover how Māori performing arts and Māori culture is interwoven. Katene describes that he, "had a yearning to understand what I was doing, to understand the cultural practices and how these things fit into performance, and how performance fits in to the culture" (personal communication,2014). This contextual learning is something that he believes is important for his tamariki to engage with at Ngāti Pōneke. Katene who has attended Club since he was "in his mothers womb," discusses one such issue involved with solely focusing on performance:

One of the biggest problems looking back on Ngāti Pōneke is that the focus has been for a long time on the performance of items, the entertainment value, that kind of thing. For a long, long time I regurgitated words that I had memorised and I had no idea what I was singing, and it wasn't until the last five-ten years that I've actually consciously focussed on learning what I'm saying... why I'm saying it? why do you do this? why do you do that? why does the flow of the waiata go like this? There are reasons for everything. It's a big thing, especially for my kids, because my boys are the same age I was when I started getting heavily into performance at Ngāti Pōneke. I don't want them to regurgitate words they've memorised. (T. Katene, Personal Communication, August 27, 2014)

This type of learning that Katene says that he was exposed to while growing up with Ngāti Pōneke aligns with the intent participation model of learning through "regurgitation" of the words and actions. In my experience, as a novice, this is an effective way to learn the physical aspects of waiata $\bar{a}$ ringa and gain an understanding of some of the musical complexities, but as expressed by Tamiahana, many questions are left unanswered about how the doing of Māori performing arts intersects with Māori culture in a holistic sense.

Leading to the 2013 regional competition, Katene combined the senior group's enthusiasm for performance, with his passion for mātauranga Māori by teaching the history and intricate nuances that make mōteatea beautiful. He wanted to do this because Ngāti Pōneke usually places greater emphasis on other items in their bracket; the popular items like the entry, exit, waiata-ā-ringa and haka. Forde, who was part of this group, explains how her perception of the traditional chant changed while learning:

$[\mathrm{O}] \mathrm{ften}$ mōteatea can be something that you don't want to learn, its just boring. But hearing Tamihana explain it...explain what every word meant and explain the passion behind it, I think, actually I really like this and I feel fine with doing a boring song, because its not boring anymore. Because you know what its talking about. (J. Forde, Personal Communication, June 13, 2014) 
Forde regards mōteatea as her least favourite to perform, but notes a new-found enjoyment of performing the chant after Katene's explanation. While this is another example of how mātauranga Māori is successfully transferred through the medium of kapa haka as discussed in chapter 3, what is important to note here is that, even during competition rehearsals, kaiako are able combine performance and learning aspects of Māori performing arts. But with competition marks awarded for performance rather than knowledge, it is common sense to spend time rehearsing the aesthetic components of performance rather than learning the knowledge that is contained within the pieces.

\section{Education Outside of the Club Experiences}

EOTC's give members an opportunity to engage with cultural aspects of Māori Performing arts and is where most informal learning takes place. I have already discussed Koroneihana as a EOTC, but there are more subtle opportunities that present themselves at Pipitea marae that allow members to engage with Māori ways of being and doing. A committee discussion is taking place regarding the action the Club should take when events that are not directly related to Māori performing arts occur on unmissable (non-cancelable) Club nights. These are important events, such as tangi, kawa mate and pōwhiri that are significant aspects of tikanga Māori. The discussion highlights the current tensions within the club regarding whether Ngāti Pōneke tamariki should attend these significant events as an opportunity to learn, or whether practices should be cancelled all together. Ryder believes that although these education opportunities may seem obvious to the older members and the parents of the juniors, these situations are not so obvious to the children. He sees it as an opportunity for tamariki to learn how to interact with, and perform in those cultural situations. He acknowledges that, "yes they're not doing kapa haka per se, but they are missing opportunities to learn what works in a Māori world” (E. Ryder, personal communication, July 27, 2014) when not attending. Tangi, kawa mate and pōwhiri are common ceremonies at marae, which is why members who are advocating for more education are eager for their children to experience these significant events. Katene, who is also a supporter of this idea, notes that this was the way that he learnt as a child:

When you think about tikanga and kawa and that kind of thing, there's a whole generation of people from Ngāti Pōneke like myself...who I don't think it was specifically taught to them, but through their experience and the respect they have for those situations it was learnt anyway, and thats the way that is was taught previous to colonisation, it was; if someone wanted a certain kid 
to learn things they would sit them down and make them watch, pay attention whats happening here, who's standing there, who's standing there. (T. Katene, Personal Communication, August 27, 2014)

Learning through experience is the process that Katene was exposed to while becoming educated about te ao Māori and tikanga. He mentions his own generation of people, who are now parents of tamariki in the junior group, who also did not learn about specific aspects of Māori culture, but who developed an understanding and respect for the seriousness of the situations. Participation, Katene believes, is an important component of a holistic teaching of tikanga Māori and he believes the more opportunities that are made available to the juniors, the greater their understanding will be of how to act in those situations. He gives the example of his own children, who through experience, know "when someone is standing to speak, you sit there and be quite, because at that point they know that person is saying something important. When you walk on to a marae and your aunty your nanny or your mum starts to call, you know (to) be quite (and) walk slowly" (T. Katene, August 27, 2014).

Yet, while Katene notes there is "no substitute for experience" (2014), much like the process of learning waiata, he is concerned that people only understand the formalities of these events because of repetition, which is not accompanied by knowledge of exactly why a certain formality is taking place. He gives the example of pōwhiri (an occasion that regularly occurs at Ngāti Pōneke because of the constant stream of manuhiri that visit Pipitea marae), where juniors are aware of processes that takes place and which order they occur, but are told why they occur. By way of example, Katene noted that juniors know when kai karanga begins to call manuhiri on to the marae, that they know to walk slowly and be seated. However, the reasons for performing karanga are not expressed; karanga are full of references to those who have died, which reminds the tangata whenua and manuhiri of those who have passed on since the two groups last met (McLean, 1996, 29). Karanga provides a spiritual function as it is "the medium by which the living and the dead of the mauhiri may cross the physical space to unite with the living and dead of the tangata whenua (Tauroa, 1986, 36)." "Everyone knows when a ko whaikorero says tena kotou tena kotou tena kotou katoa then you stand up to sing for them, [but] why?”' Katene continues:

and with the pōwhiri process, when one person stands on one side, the order of the speakers is [iwi] specific. If its pāheke...the tangata whenua gets up and speaks one after the other and then crosses over to the manuhiri and they speak one after the other. If [you are in] tau-utuutu...one starts here and then reply, reply, reply...there's a lot of complicated things within those practices...I'm doing wānanga with our people to learn why things happen in a pōwhiri. It's complicated, but the good thing is that once I go through this journey of learning then I can make important for the people who are with me as well to understand this is why they're doing that. (T. Katene, Personal Communication, August 27, 2014)

Katene, who is in the process of learning about these aspects of Māori culture himself, believes it is important to move beyond solely experiencing correct procedure of these 
occasions, to an informed understanding of why they occur; a concept that will not only educate tamariki about Māori history, but also serve to educate current members who will one day be leaders of the Ngāti Pōneke Young Māori Club.

\section{Matters that Prevent Informal Learning at Ngāti Pōneke}

Beamsley notes that in order for "that deep learning of te reo, that understanding of the actions that go with the words and the meanings behind the waiata and the haka...[this is] dependent on the structures that you have within the club." One such structure that is needed is how to best disseminate this knowledge with a kaiako to tamariki during rehearsals. The decision on who leads the group is often dependent on who is available. With modern-day commitments, it has proven difficult for Ngāti Pōneke to find a kaiako that can regularly take junior rehearsals. While I have been attending Ngāti Pōneke, the kaiako has changed from month to month, sometimes even weekly. I have been told that before I joined Ngāti Pōneke that there was a regular kaiako who was as Beamsley states, "someone who advocated for the children's understanding about what they were doing." For Beamsley, imparting contextual knowledge to tamariki is an important part of junior participation at Ngāti Pōneke.

There is a feeling by some, that having a kaiako who has extensive knowledge of mātauranga Māori will help drive the club into the future as Ryder explains:

The ideal is that the environment that is provided is total immersion, and that is where the reo is learnt the easiest I find, but the reality is that not everyone that kiako are fluent in te reo and so we can't say, you can't teach because you're not fluent. So it is an aspiration so I think as long as well hold that as an aspiration then we can't go wrong. (E. Ryder, Personal Communication, July 27, 2014)

The informal learning process and "total immersion" is only possible if a suitable and knowledgeable leader is available. Occasionally a senior member will take on the roll and lead the practice, but lately Michael, the lead guitarist, has taken on the roll of kaiako. Michael is regarded as a great leader and has an extensive knowledge of Ngāti Pōneke’s repertoire; not to mention, his intricate guitar style is able to drive the junior kapa haka group and keep them unified. However, English is the predominant language used at club nights.

While much of the direction of the club relies on the kaiako, there is another factor that revolves around the facilities that Ngāti Pōneke use to practice:

It (the direction of the club) goes in waves really and it depends what is happening because remember this is only an hour and a half once a week. (T. Beamsley, Personal Communication, July 23, 2014) 
We only come together basically once a week, and to cram everything into a one hour period is a lot harder than we think, but it's difficult because we don't live there we don't live on the marae. (E. Ryder, Personal Communication, July 27, 2014)

Beamsley makes the point that the committee needs to consider, with any decision they make, the limited amount of time that Ngāti Pōneke have with Pipitea marae, and, with only an hour and a half each week, it is considered unfeasible to concentrate on education with such little time resources. Similarly, Ryder notes that Ngāti Pōneke do not live at Pipitea marae, a reality that is afforded to other iwi (and Māori performing art groups), and is a constraint that must factor into educational decision making. The time that Ngāti Pōneke have at Pipitea is gifted to them, and as Ryder describes, the politics of who controls the marae as essentially an 'events centre' can cause disruption for the Club, especially for those who consider Pipitea marae home:

What's difficult is when the land under the marae was given back through the tribunal claim to Taranaki whanau...(it created) a different understanding of the role that Ngāti Pōneke plays at Pipitea marae and it created another entity that felt they were the owners of Pipitea marae. We're still having a discussion about, is Pipitea marae the home of Ngāti Pōneke? and although Ngāti Pōneke fundraised to build the marae, and it took them over ten years top do that...a lot of the money that was given towards the building of pipitea marae was given by the Wellington public...At times I've felt that our presence at Pipitea...I look at Pipitea as just a space for hire, that we are hiring, and when we are dictated to and told when we can and when we can't use what we consider our home, then it makes it feel less like home. (E. Ryder, Personal Communication, July 27, 2014)

Ryder's view towards Pipitea marae is that the space is run in a businesslike sense, rather than, in his view, in consideration of the wider Māori community who it was intended to originally serve. I can cite experiences of my own where I have walked in to the whare tapare to find several hundred chairs set for a week-long conference. Ryder has also described situations where he went to Pipitea marae outside of rehearsal hours and felt as though he is "on someone else's property." He believes the marae has strayed from its original intention, which was "to provide a space and a shelter for Māori in the Wellington area that wanted to do things Māori but didn't have the capacity to go home to do it. So basically providing them a second home. It's far from that at the moment" (E. Ryder, Personal Communication, July 27, 2014). The view of most in Ngāti Pōneke is that Pipitea marae should be used for local, national and international communities to engage with Māori performing arts and Māoridom. But as it stands, the marae is regularly hired for functions that prevent performing arts engagement. Ngāti Pōneke occasionally provides kapa haka entertainment for groups that hire the marae, which further encourages the the club to focus on presentational performance. 


\section{Koroneihana Celebration}

Returning to the Committee meeting discussed at the beginning of this chapter, the EOTC to Koroneihana was achieved and it was regarded as a success for those in the committee who advocated for the trip. Ryder noted that, "for the past year we have been learning for the sake of learning and there was no real incentive, there was no real focus," but when the invitation was extended to Ngāti Pōneke, the Club leaders saw it as an opportunity for both presentational performance and informal learning. It would give those who attended an opportunity to better understand the celebrations importance. It combined elements of performance and education, while also building whanaungatanga of the members of Ngāti Pōneke and wider Māori community.

This was the first time that Ngāti Pōneke had all age levels performing at Koroneihana, which, for the months leading up to the celebration, gave all members of the Club an incentive to attend rehearsals and construct a performance bracket. While traveling back from Ngāruawahia on the bus, a kuia made an announcement on the busses PA system, praising the Club for the effort they put in to their performance. She continued, "When you go on a trip, you need all the evidence we've got to show that we can go on another trip." In her view there was an overwhelming amount of evidence that the club should perform again at the celebration next year. Koroneihana energised the Club to perform more in the community as well as attend more experience related events.

The position of Māori performing arts and the purpose it serves Ngāti Pōneke is fluid and subject to change; the club's position on how Māori performing arts should be utilised is dependent on structures within the committee, the skill sets that members are able to offer the group, and the club's performance schedule. Ngāti Pōneke is continually trying to find a balance between (1) focusing on presentational performance and performing well in public to attract new members, and (2) intergenerational transmission of Māori knowledge, culture, language and custom that tamariki may confidently lead Ngāti Pōneke into the future. There is a need to draw young members to the club, most of whom are attracted by the prospect of performing in public, while also educating young members about Māori cultural practices so that they may pass their knowledge on to the next generation of Ngāti Pōneke members. The differing opinions on whether Ngāti Pōneke should attend Koroneihana and perform serves as a symbolic talking point on what use Māori performing arts has within Ngāti Pōneke and in wider Aotearoa New Zealand. 


\section{Chapter 5}

\section{Connecting to Aotearoa}

New Zealand

At this point in the thesis I discuss the reasons why diverse communities engage with Māori performing arts. Māori performing arts connects people in three overlapping classifications of local, national and international community. Within these communities, participants voiced four different methods within Māori performing arts that connect people to their community: performance and mana, place and space, whanuangatanaga, and an appreciation for Aotearoa New Zealand culture. These four themes link those who experience Māori performing arts to Anderson's concept of an "imagined community" (2006). The imagined community is a comradeship of people who are informed about Māori ways of being and doing. The community exists on two fluid levels, (1) Māori performing arts is the medium through which people are informed about Māori knowledge, language, culture, and custom and (2) Māori performing arts is the means through which Māori ways of being and doing is expressed back to the community. It is "imagined" because even if members of this community do not meet face-to-face, they are still considered part of their communion and fraternity $(2006,6) .{ }^{27}$ This communion is founded on representing sentiments of Aotearoa New Zealand that Māori performing arts provides participants.

\section{Performance and Mana}

I have already discussed in this thesis how performance of Māori performing arts is a vehicle for positive mental and physical wellbeing (Paenga, 2008). In addition, most depend on

27 The term "imagined" does not imply that the community is somehow fictitious or false; it is more important to look at how the community is imagined, and the style through which it is imagined (2006). 
performance to connect local communities to the national community. At the local level, performance solidifies iwi and hapu identity while at a national level, kapa haka competitions and events (i.e. Koroneihana) provide for a broader embracing of Māori and New Zealand identities.

Performance is connected to and communicative of the concept of mana. ${ }^{28}$ "People of mana draw their prestige and power from their ancestors (mana tipuna). This power is socially founded upon the kinship group, the parents, the whanāu, hapū and iwi'” (Mead, 2003, 37). Mead goes on to say, "as a general rule mana must be respected and public events should enhance the mana of participants"(37). Māori performing arts groups express mana during presentational performances; waiata composed by whanau and ancestors are performed to audiences who expect to witness a polished performance and one that is representative of the group's identity.

An example of how performance is an expression of mana and a medium that connects people to local and national community is the Koroneihanga celebration that I attended with Ngāti Pōneke (discussed in Chapter 4). A group of forty from Ngāti Pōneke travelled to Ngāruawāhia to perform at Koroneihana, a celebration of Kiingi Tuheitia's coronation. There was a focus on education as well as performance. People came from around the country to celebrate at Tūrangawaewae marae through sports fixtures and musical performances. Stalls were set up to educate people about Tūrangawaewae marae and the history of the Kiingi movement. An event organiser noted the celebration was about "people coming together." People were drawn to Koroneihana to perform and express mana through performance to other Māori performance groups from around the country.

Ngāti Pōneke were one of a dozen Māori performing arts groups that performed throughout the day. Some groups refined their bracket for the national competition and used the celebration as an opportunity to gain performance experience before Te Matatini the following year. Although Ngāti Pōneke was not preparing for a kapa haka competition, there was a desire to perform well. Nerves were high and tensions rose as we prepared throughout the day for the afternoon performance; the quality of Ngāti Pōneke's performance directly affected the group's reputation and mana. A rivalry exists between competing performance groups and Ngāti Pōneke needed to maintain its reputation as an excelling performance

\footnotetext{
${ }^{28}$ The word as defined by Williams (1957:172) has a range of meanings: 'authority, control', 'influence, prestige, power', 'psychic force', 'effectual, binding, authoritative.'
} 
group. ${ }^{29}$ This energised the group as Ngāti Pōneke's high standard of performance would attribute to enhance the mana of Ngāti Pōneke iwi.

Ngāti Pōneke's presence at Koroneihana was conducive to being part of the national Māori community. There was a conscious choice on behalf of the kapa haka leaders to perform well-known pieces that would preserve Ngāti Pōneke's reputation for being a competent entertainment group while also including the audience who sung in unison while we performed. Speaking of our audience reception, a kuamatua noted:

ya know they're sick of competitions, at the breakfast table people were stopping us and telling us we were really delightful you made their day and they were grateful that they stayed to the end.

Māori performing arts groups usually come together to perform in preparation for competition. Koroneihana, however, was about celebrating Māori ways of being and doing and feeling connected to the national Māori community.

The physical act of performing with a group in unison and expressing individuality to an informed audience solidifies local community identities. Koroniehana was an opportunity for Māori performing arts groups to strengthen their own relationships and express their distinctive performance styles. Ngāti Pōneke's unique and distinctive feature as a generationally inclusive performing group was displayed; leading the haka portion of the bracket were twins only six years of age, something that was not seen by the other groups. Kaumātua stood at the back and supported the parents who supported the tamariki at the front. Playing guitar, I stood in the middle with two other guitarists. On display was an allinclusive group, performing with members of various ages to Kiingitanga, a figure who represents Māoridom in Aotearoa.

Ryder noted at the conclusion of the trip that although we all associate with different iwi, “everyone was Ngāti Pōneke on this trip.” Ngāti Pōneke presented their unique brand of Māori performing arts by performing Ngāti Pōneke specific waiata and tamariki lead haka. They expressed their identity while being part of the larger community of Māori who had come together to celebrate Kiingitanga and be part of Māoridom.

\footnotetext{
29 Whitinui (2012) has noted how kapa haka has revived a new kind of rivalry between Māori. Haka, which was used to respond or challenge iwi on the battlefield, is now being replaced by competing on the stage.
} 


\section{Place and Space}

Place and space are referred to here in the context of human geography; space is something abstract that holds no substantial meaning, while place refers to an emotional connection or awareness of attraction to a certain space. What begins as undifferentiated space becomes place as we denote value upon it (Tuan, 1977, 6). Pipitea marae is a space where the local Māori community can meet and engage with Māori culture. The marae challenges notions of iwi ownership due to Ngāti Pōneke's pan-iwi formation and identification. Members are motivated to regularly attend Pipitea marae and participate in Māoridom because of the dedication and commitment that Māori performing arts and the Ngāti Pōneke Young Māori Club requires. It is the desire to perform that draws members to Pipitea and creates a community where Māori can be Māori in Wellington. Pipitea marae is a space for the local Māori community, the Ngāti Pōneke Young Māori Club, to foster a sense of place for Māori to engage with Māori knowledge, language, culture and custom.

The affection that is felt towards Pipitea marae is grounded in the formation of the Ngāti Pōneke club. In The Silent Migration, stories of how the Ngāti Pōneke Young Māori Club came to fruition are described as a "culture in transition within a country in transition" (Grace, $2001,1)$. In the 1930s, New Zealand was facing a large migration of people to the city from rural areas in search of employment, most of whom were Māori. NPYMC provided Māori an environment to engage with Māori ways of being and doing in a city that was fixed on Pākeha ways of being and doing. It became somewhere people could support each other as Beamsley explains:

I think it always was, the home away from home, for Māori coming to live in the urban area. I think it always was about whakawhanaungatanga and support...for Māori that had moved form the rural areas into...Wellington. (T. Beamsley, Personal communication)

The Māori performing arts group within Ngāti Pōneke provided an opportunity for Māori to support one another during a time of cultural and societal transition. The group became a metaphysical "home away from home." While this large migration shift is no longer occurring, Pipitea marae is a space, and the Ngāti Pōneke Young Māori Club a place for Māori to be Māori in Wellington, as new members of Ngāti Pōneke have articulated to me.

Jules Forde joined the club in 2013 after a friend encouraged her to be part of Ngāti Pōneke's regional kapa haka competition campaign. Growing up, Forde was heavily involved with her school kapa haka groups in Wairoa and Wellington, often being called upon to lead, but between 2010 and 2013, Forde did not perform Māori performing arts as she was unaware of any adult groups in Wellington. "So I just started going along," Forde continues: 
and I really enjoyed it and everyone was real cool and [we] just became family after awhile, it was cool to be back into it, because you don't really realise how much you miss...that sense of family when you're around Māori people because for like two and a half years I wasn't around any Māori people and I wasn't around the culture at all and so I didn't really think about it. (J.Forde, personal communication, June 13, 2014)

Forde missed being "around the culture" and even neglected how much she enjoyed that sense of being around Māori people that being in a Māori performing arts group is able to provide. Upon attending Club, Forde relished being amongst like minded people. Since our interview, Forde has since begun studying at Victoria University, subsequently leaving Ngāti Pōneke to join the University kapa haka group. Nonetheless, Ngāti Pōneke provided Forde with an opportunity to reconnect with Māori culture before moving into tertiary education.

Much of what draws people to rehearsals is the connection that members have to the rehearsal space, Pipitea marae. However, Pipitea marae is much more than an area to perform kapa haka and Māori performing arts. "When I think of Ngāti Pōneke," Beamsley explains:

I think of Pipitea marae, I feel very much connected to Pipitea marae, even though I had nothing to do with the building of it or anything like that, but I feel very much like thats my marae here in Wellington where I've been brought up and if I knew what had happened to the hall we use to go to I would have purchased it if I'd been able to...I very much think that Ngāti Pōneke is part of the Wellington landscape, and you can build wharewaka and flash places and that kind of thing, and once upon a time of would have said, "yep Pipitea is just a concrete house that's not really alive," but since my involvement with Ngāti Pōneke in the last eight years I have come to feel a sense of ownership of the marae, a sense of warmth, even when the kids don't listen to me... (T. Beamsley, Personal Communication, July 23, 2014)

Beamsley's attachment to Pipitea is founded on a community wide acknowledgement that Pipitea marae is the home of Ngāti Pōneke. Trish feels ownership of "my marae," not because of the physical structure, but the relationships, experiences, and knowledge that have been encouraged by Ngāti Pōneke. Accordingly, Pipitea marae is unlike other purpose-built 'Māori cultural' structure in Wellington. The Club played a large part in fundraising for the building of Pipitea marae, but even without financial help, Pipitea would not be the same. Without Ngāti Pōneke, Pipitea would not be recognised as "part of the Wellington landscape" and, equally, without Pipitea marae, Ngāti Pōneke would not have a space to exchange knowledge. The value, emotional attachment, generosity and hospitality of Pipitea marae is attributed to the Club's sense of ownership. Walking into Pipitea marae on club nights, there is distinct awareness of Ngāti Pōneketanga; from the waiata that are specifically Ngāti Pōneke owned, to the continual referring to each other as whanau, Pipitea marae is Ngāti Pōneke’s place. 


\section{Whanaungatanga and Connectedness}

The emotional connection and feeling of place and home that participants feel towards Pipitea is created by the Ngāti Pōneke members that frequent the marae. Māori performing arts allows people to share in a communal music making experience, which encourages whanaungatanga and feelings of connectedness to the local community. On my first visit to a Ngāti Pōneke rehearsal, members conveyed manaakitanga, hospitality and warmth to me and to existing members. Many members were introduced to the Club through whanau links, but there are many who do not have kinship ties and were introduced through colleague, friend or community relationships. My expectations attending the first rehearsal was to find a group of people passionate about Māori performing arts, but this was only one dimension to the various functions that Ngāti Pōneke serves:

Its not just the kapa haka and I've said a couple of times- had I discovered Ngāti Pōneke before I discovered black power, chances are my patch would have been a Ngāti Pōneke one because they gave me the same camaraderie, whanaungatanga and support as what I was getting from the black power- its a pity I didn't discover Ngāti Pōneke a lot earlier. (E. Ryder, Personal Communication, July 27, 2014)

The Ngāti Pōneke Young Māori Club provides Ryder a sense of whanau connection that was previously satisfied by his membership to the black power gang. Regardless of family ties, Ngāti Pōneke is founded on the principle of whanaungatanga, which "extends beyond whakapapa relationships to non-kin persons who become like kin through shared experiences and to the ancestral house at the marae" (Mead, 2003, 36). While Pipitea may not be an ancestral house in a strictly traditional sense, some recognise and identify with Ngāti Pōneke as their iwi and Pipitea as their marae:

I remember back a few years ago I introduced myself...we were going to a whanaungatanga session and I named Ngāti Pōneke as one of my iwi and one of the kaumātua got up and said it was the first time he had heard that and I was shocked because I thought everyone would identify with Ngāti Pōneke. But I do see...[how] Ngāti Pōneke was an entity of its own, it was the first kapa haka group in the country in terms of urban kapa haka group, non-tribal... (E. Ryder, Personal Communication, July 27, 2014)

Ryder naming Ngāti Pōneke as one of his iwi along with his whakapapa, demonstrates the significance of Ngāti Pōneke as a social unit. Ngāti Pōneke's significance is owed to the many hundreds of people who have come through the group ("so many people have been a part of it"), and the ethos and prestige that comes with being, "the first [urban] kapa haka group in the country." Ngāti Pōneke's formation in 1937 was unprecedented and has, as an "entity of its own," gained an esteemed reputation in Aotearoa New Zealand, and one that Ryder is proud to express. 
However, Ryder does not identify with Ngāti Pōneke because of its reputable history, he claims "to be Ngāti Pōneke because of the personal relationship and experiences that I've had with Ngāti Pōneke, and I know that Ngāti Pōneke changed my life.” Similarly, Beamsley describes her attachment to Ngāti Pōneke through her relationships with people; "I feel like they're my extended family...you know because you can't choose your family." This notion of extended family reverberates around the Ngāti Pōneke community when tangi and kawe mate are held at Pipitea marae, often on club nights. A message is sent over email notifying members of such a proceeding; and while members would attend these occasions to pay their respects, there was also an expectation that many would attend so that they can perform as a way of paying their respects.

Whanaungatanga at Ngāti Pōneke is best symbolised by the respect that younger members show to the elders of the club and how certain characters are representative of the iwi:

Even today there's people, there's faces of Ngāti Pōneke- Donas and Bill. When people look at them they are looking at Ngāti Pōneke, so my goal is when they are looking at any one of us, they're looking at Ngāti Pōneke and know that they are. (E. Ryder, Personal Communication, July 27, 2014)

Faces that represent the Club are the kaumātua of Ngāti Pōneke. There is a desire amongst the parents of the club to carry Ngāti Pōneke passionately into the coming years, both for the benefit of their tamariki and out of respect for those who formed the Club. Ryder recognises certain "faces" as being representative of Ngāti Pōneke and expresses an aspiration to also be a member that personifies the mana of the club. The older members essentially serve as kaumātua of Ngāti Pōneke as their knowledge and leadership demands respect and recognition from the younger members who look to them for guidance. Not only does this reinforce an awareness of whanua, but also of whakapapa and lineage to those who started the club.

The activities that Ngāti Pōneke offers members has changed over the years. Initially, the Club catered to many social activities; there was a netball and rugby team, as well as regular church services. However, due to other highly organised sports and cultural clubs that currently operate around Wellington, people have found alternatives to Ngāti Pōneke. Additionally, there are more Māori centered activities that offer a similar expressions of Māori identity, one such example being the Iron Māori competition that some members of Ngāti Pōneke are involved in. This has unfortunately lead to a decline in regular member turnout, and a decrease in the number of people at kapa haka practices on Mondays. Members fondly remember a time, only five years ago, when more than a hundred juniors would fill up Pipitea whare tapere for practice. But due to kapa haka now being facilitated in schools and work 
places, Ngāti Pōneke's once unique offering of Māori performing arts is able to be facilitated elsewhere.

In the previous section I discussed the declining membership of Ngāti Pōneke. But while people leaving Ngāti Pōneke to join other groups is certainly undesirable, there is a feeling of solidarity and comradeship that is felt about previous members:

[T] here are people in most kapa haka groups around the country that were either junior or intermediate members of Ngāti Pōneke, and some seniors. It's cool when we watch the nationals and see some of our members in other groups, but it's kind of not cool because we want them to be part of us as well. (E. Ryder, Personal Communication, July 27, 2014)

Members who join Ngāti Pōneke are part of a community of Māori performing artists who have learned and performed with the club. They have been part of Ngāti Pōneke's identity through performing in the uniform and singing Ngāti Pōneke waiata. It is positive for Eugene to see them progressing with kapa haka albeit at the expense of a smaller Ngāti Pōneke membership.

\section{Appreciation of Aotearoa New Zealand Culture}

Māori performing arts provided students in Te Kōkī New Zealand School of Music course an opportunity to develop an understanding of New Zealand culture. New Zealand culture, in its broadest sense, is influenced by British colonisation with an interwoven presence of Māori and Polynesian tradition; Māori performing arts as expressed in New Zealand today, is a symbol of this relationship. ${ }^{30}$ Māori culture, which is promulgated as one of two in bicultural New Zealand, is often advertised to an international (and sometimes national) audience, as being representative of New Zealand nationhood, usually for tourism purposes. For many in PERF 151, gaining an appreciation of New Zealand culture is the primary reason for enrolling in the class.

Ka Mate is one such piece that romanticises this relationship as uniting Māori and Pākehā. Katene chose to include this haka in his introductory course due to his own whakapapa lineage to the piece, and the prolific nature of the haka in New Zealand and around the world. Most students already had some knowledge of Māori performing arts before undertaking the course due to their awareness of Ka Mate. For most students, the All

\footnotetext{
30 This relationship is fluid and ever changing. The genesis of one such performance context, kapa haka, is a conscious effort of Māori to distance themselves from Pākehā arts in the twenty and twenty-first centuries. Considered an invented tradition (2008, 117, Papesch), kapa haka is viewed in New Zealand as an entirely Māori owned expression while some European musical traits are audible in kapa haka.
} 
Black's interpretation and presentation of $\mathrm{Ka}$ Mate at the beginning of their rugby test matches had been their first experience of Māori performing arts. Due to the popularity of this haka, and the energy and passion that performers exude, Ka Mate is consequently a significant factor for them in wanting to further their knowledge in this area.

\section{"Ka Mate": a gateway for national and international communities}

Ka Mate, composed by Te Rauparaha (see chapter 2 for detailed description), has been popularised and closely associated with the New Zealand All Blacks since the "New Zealand Natives" 1888 tour of Britain (Natives' Rugby Tour, 2014). For most non-Māori New Zealanders, their knowledge of Māori performing arts is perhaps limited to the All Blacks most performed haka, Ka Mate. ${ }^{31}$ Similarly, as the team is also the most prolific proponents of haka overseas, the haka is the All Blacks most distinctive feature for international spectators.

Tim Dustow, who grew up in Hawkes Bay, notes that one of his first experiences of Māori culture was watching the All Blacks perform Ka Mate on Television. When asked if he associated Māori performing arts with the national rugby team he responded:

probably, I don't think I fully understood that it was Māori though, you know when you were a kid, it was just normal. And because not everyone who was in the team was Māori you just attach it to New Zealand more than an actual Māori culture. I don't know if I fully understood that it was Māori when I was young. It's just what the All Blacks do. (T. Dustow, personal communication, May 22, 2014)

Tim's experiences of Māori performing arts are concentrated on performances represented by the national rugby team and aligns with many other New Zealanders experiences. As a child, Tim perceived haka as being "attached...to New Zealand" rather than Māori culture specifically. This is a common perception of Ka Mate. Its significance is often mythical and popularised in the memory of New Zealanders and is often viewed as uniting Māori and Pakeha (Maclean, 1999; Zavos, 1998). Its popularity and attachment to national identity may be because the haka is performed during heightened moments of national significance as the team face foreign opponents (Jackson \& Hokowhitu, 2002). ${ }^{32}$ It is a time when a large proportion of the nation's population is focused on fifteen men, who, before entering the sports battlefield, demonstrate "a unity of passion, commitment, and assertiveness that,

$31 \mathrm{Ka}$ mate is not the sole haka performed by the team. Before a test match in 2005, the All Blacks performed Kapa O Pango for the first time, a haka composed especially for the context of the game. This new haka created some controversy, however, as many spectators interpreted one particular action as too aggressive when the leader drew his outstretched thumb across his throat. This was misinterpreted by many as "throat-slitting" and as a consequence the action was amended.

32 The word 'haka' is sometimes associated with the national rugby team, rather than a genre compositions that are accompanied by instruments of the body, and 'doing the haka' is synonymous for performing Ka Mate in a similar style to the All Blacks. 
although explicitly masculine and uniquely New Zealand, is expressed in Māori terms" (2002). Although being expressed in "Māori terms," performing the haka has become an essential part of the All Blacks sporting event and consequently perceived as being "owned" by the All Blacks, as Tim's experiences suggest:

I hadn't seen it anywhere else I suppose, I hadn't seen a Māori group do it anywhere. I think I thought that it belonged to the All Blacks. I didn't realise that it hadn't been written for the All Blacks and I didn't find that out until I was probably at intermediate or something. I always assumed it was written for the All Blacks, like oh that was there dance that they got taught. (T. Dustow, personal communication, May 22, 2014)

The All Blacks' representation of Māori performing arts, combined with their popularity and cultural capital, had led Tim as a child, to assume that it "belonged to the All Blacks." In Metro magazine, Ranganui Walker writes, "the haka (Ka Mate) as a prelude to a (rugby) test match has become as much an icon of national identity as the All Blacks themselves" (Walker 1996, 125 cited in Murray, 2000). This puts Ka Mate in a unique position as an indigenous performance as it is represented in a variety of performative contexts (Murray, 2000).

From an international student's perspective of Payal's experiences, Māori performing arts was through an All Black representation as she notes, "It was only when I was first deciding that I was coming to New Zealand I saw a video of the All Blacks doing a haka before they played and that's it, literally it." The All Blacks promote an image of Māori performing arts, haka in particular, that, by default represents New Zealand culture as a whole, rather than specifically Māori or Ngāti Toa. Performed after the national anthem in te reo Māori and English, fifteen men, who are idolised in popular New Zealand culture, perform haka which is received by the nation and international community as being uniquely representative of New Zealand. This coincides with Payal's exposure to the commercial tourist image that was sold to her while researching New Zealand as a destination to study:

They sort of sell the image, to I guess foreigners, that Māori culture is like this huge thing here now, and I know it only had a resurgence in the eighties, right. So it's sort of like a top-down resurgence...but from the outside perspective they make it seem like Māori culture is more prevalent than anything else. (Personal Communication, Payal, 2014)

For Payal, Māori performing arts, as represented by the national rugby team, is solidified by how Māori culture is packaged and sold as presenting an image of New Zealand culture as a whole. Consequently, engaging with Māori performing arts, is seen from an international student's perspective as a way to become immersed and gain an appreciation of New Zealand culture and also connect with New Zealand as a country. 


\section{Appreciation of Māori Culture and Connection to Iwi}

Some students also enrolled in PERF 151 to appreciate Māoridom and its position within contemporary New Zealand. Katene's education of Ngāti Toa-specific performing arts provided many students with an avenue to engage with a particular sect of Māori culture. The histories and knowledge contained within waiata enabled students to connect with the local Ngāti Toa iwi community. Katene made it clear that he was facilitating an iwi specific narrative to the class, but would often make references to broader Māori culture and Māoridom when discussing tikanga.

In a survey response ${ }^{33}$ one student notes, "I want to be an early childhood teacher and Māori language and song is a good knowledge to have." Having knowledge of Māori performing arts is viewed by this student as being valuable to communicate in mainstream early childhood education. Another student's reason for enrolling in the course is to use the class as "a medium for learning about Māori culture." While Tamihana primarily discussed his experiences and ethos of Ngāti Toa, students were exposed to an alternative worldview and Māori identity. Māori performing arts aids in this process because it is a "culturally responsive curricula" (Whitinui, 2010); and through movement, students are able to "remember their cultural past and bring those memories, stories, narratives, life-histories, values, beliefs and ways of knowing and doing into the present" (7). ${ }^{34}$ Instead of "remembering" as Whitinui suggests, students in the class are experiencing Māori culture for the first time and consequently imagining the past; a past which is then reenacted and experienced through Māori performing arts. Learning historical Māori narratives gives students the ability to make personal connections to Māori ways of being and doing. "I think that exposure to another culture," one student explains, "helps you understand it and builds connections in Māori community." An affinity and connection is felt, not only to the performing arts community, but also with the Māori community at large. This connection seems to be determined by who is distributing the knowledge. Student's experiences of Māori culture were directed by Katene who is a highly passionate and knowledgable Māori performing arts facilitator. It is this perspective that allowed students to connect with the Māori community as Payal explains:

I'm always a little bit weary about learning history from only one source, it's pretty easy to hear about New Zealand's history from the western perspective, you just go to the library. I'm really glad that...I'm not saying that Tamihana represents the whole entire Māori history, but I'm glad

\footnotetext{
${ }^{33}$ I chose week seven because, by this time, students would have had enough time to engage with the material, but also be able to recall their expectations coming in to the course in the initial weeks of the semester.

34 While Whitinui's study focuses on Māori high school students engagement with kapa haka, non-Māori students are equally able to learn through physical movement and understanding of the waiata, Mōteatea and haka that they perform.
} 
that I got to see it from another perspective besides the western one. (P. Patel, personal communication, May 4, 2014)

Katene taught waiata, haka and mōteatea that were personal to him; they were from Ngāti Toa and written by and for his whakapapa. Consequently, the history and narratives that he gave were personal and emotive for him, which was transferred to the students. Katene's close connections with the composers of the performance pieces gave students a similar immediacy to the composers and waiata narratives.

One student reported that they enrolled in the course, "to learn more about Māori tradition and language/music, as well as how Māori culture integrated into the overall modern New Zealand culture." A “modern" New Zealand refers to New Zealand's stronger commitment to biculturalism, where Pākehā and Māori culture may exist on equal terms. This commitment began in the 1970s with the introduction of the Waitangi Tribunal and other government agencies, who implemented policies to promote a bicultural society. Accordingly, this student is wanting to garner an understanding of New Zealand's wider bicultural context and found the course being useful in understanding the relationship of Māori culture in twenty-first century New Zealand. ${ }^{35}$

35 "Post-colonialism" may be the insufficient to assign to New Zealand as the term implies that colonialism is finished business, when in reality it still has a profound affect on indigenous people (Smith, 2012). 


\section{$\underline{\text { Conclusions }}$}

My focus for this study has been how Māori performing arts connects participants to Māori and New Zealand communities. After eighteen months of participating in two Māori Performing arts communities I have not only discovered a wealth of knowledge pertaining to Māori culture, but have also established strong friendships within the performance community. Māori performing arts and culture has contributed to my musical and personal identity. By examining the experiences of performers and their connection to Māori culture this thesis reveals that Māori performing arts provides a strong link to Māori knowledge and Aotearoa New Zealand community.

Building on ethnographic methodologies of participant observation and researcher perspectives, this thesis investigates Māori performing arts in Māori communities and outside of Māori spaces. It explores how engaging with Māori performing arts connects people to Aotearoa nation through: (1) the value that Māori performing arts can offer Māori and nonMāori by providing a platform to connect with Māori and New Zealand culture, (2) The intrinsic link between Māori performing arts Māori cultural identity, most of which is derived from feelings of connectedness and whanaungatanga that performing arts enables, and (3) the significant contribution the performing arts attributes to New Zealand's national identity and representation, which is instrumental in how international audiences perceive "us."

The terms 'access' and 'opportunity' emerged through Māori and non-Māori participant descriptions of their experiences with Māori performing arts. It cultivates a means where non-Māori can access Māori language, history, culture and custom, and offers individuals an opportunity to further traverse te ao Māori. The arts provides an atmosphere where non-Māori feel they may safely engage with Māori culture without fear of appearing culturally uneducated. Participatory performance (Turino, 2008) gives non-Māori a 'safety-innumbers' confidence when learning waiata. It offers a space where mistakes can be made and corrected in an open learning environment. Agency rests with Māori tutors who control the knowledge and ensure the knowledge is interpreted correctly. 
It is a medium for Māori who are disengaged from iwi, hapu and whanau to connect with Māori ways of being and doing. Māori performing arts is a tool for building and strengthening New Zealand's identity through heightened moments of presentational performance (2008) and creates meaningful connections within the local, national and international community.

\section{Gateway for Māori and non-Māori into Māori Culture}

A second major area of this thesis investigated the diverse reasons Māori engage with performing arts. For members of Ngāti Pōneke, club nights are a place where people can connect to Māoridom and knowledge. Club nights are also a space where individuals can connect with each other through the camaraderie that performing in unity fosters. Most members regard Ngāti Pōneke Young Māori Club as an iwi and Pipitea marae as "their" marae and a home away from home. Performing arts provides the necessary motivation for individuals to attend weekly rehearsals and Pipitea marae provides a refuge and place to belong, especially for members who live away from kainga and whanau. This particular marae provides a space for members for Ngāti Pōneke to practice tikanga on a weekly basis and grants kaumātua an opportunity to transmit knowledge to tamariki.

Non-Māori participants express that participating in Māori performing arts is a culturally safe way to access Māori culture. Students cited initial feelings of apprehension about engaging with te ao Māori in the introductory course; there was a sense of appropriation that participants felt about performing an art that they have internalised and normalised as being Māori owned. This notion is grounded in students' experiences at school where Māori performing arts (and Māori cultural experiences) were included in the curriculum, but managed with undertones of tokenism. New Zealand is proud to represent itself as bi-cultural society, yet this balance was not seen throughout their formal education. After engaging with Māori performing arts under the supervision of a knowledgable tutor, students noted increased feelings of confidence about their ability to navigate te ao Māori. It gave them the ability to develop a base knowledge of Māori ways of being and doing, which they could use as means to further their learning of Māori culture. It provided students with an access point to Māori culture and an opportunity to further their knowledge.

Throughout this thesis I discussed the approachability of te ao Māori within a music performance context. Students at Te Kōkī had some previous understanding or experience with music performance which enabled them to access Māori culture through a musical 
framework. Based at NZSM and with a course code PERF (performance), students would have needed to actively search for a 'music' or 'performance' course through the New Zealand School of Music website. In 2010, PERF 151 was a joint venture between Te Kawa A Māui and NZSM and attracted a large number of students, most of whom were on international exchanges. The course enabled students to broaden their musical and performance experiences while also engaging with Māori cultural ideas.

Students familiarity with music gave them the ability to map their already sturdy relationship with music onto Māori performing arts. This was aided by the egalitarian nature of Māori music performance; waiata, mōteatea and haka, while performed in musical unison, are also learnt together. The intent participation (Rogoff et al., 2003) style of learning performing arts in an informal process establishes a safe environment to learn. It creates a kinship amongst students and enables them to support each other while connecting with Māori culture. This sentiment is also true for inexperienced performers who attend club nights at Pipitea; people can join the back of the group and learn while imitating the person in front of them.

Presentational performance motivated students to thoroughly intrench themselves in Māori culture due to the holistic connection between Māori performing arts and Māori knowledge. A "good" performance in the courses final assessment is the result of an informed understanding of Māori knowledge. It is not possible to perform Māori performing arts well without having an understanding of the knowledge contained within the pieces and consequently, students are incentivised to thoroughly comprehend te ao Māori to perform. This is a motivation that would not exist in nonperformance based Māori cultural courses. A tension between Māori performing arts as presentational or participatory (Turino, 2008) is occurring in local performance contexts. This tension highlights the current views on how the performing arts should be utilised.

\section{Local, National and International Community}

Performing arts connects Māori to local and national community identities in New Zealand. I cited the example of Koroneihana as a communion of kapa haka groups who expressed their iwi/hapu identity to the wider Māori community in the presence of Te Arikinui Kiingi Tuheitia, a figure who for many represents nationwide Māoridom. Participants express mana during performances to other Māori performing groups. This serves to both solidify local iwi and group identities as well as connecting Māori to the national community. As an informed 
imagined community (Anderson, 2006), Māori identify with the knowledge that is contained within the pieces they perform and connect with other local communities during kapa haka celebrations. For non-Māori New Zealanders, Māori performing arts is seen as being owned and bound to Māori communities. Accordingly, non-Māori perceive their engagement as connecting to nationwide Māoridom, rather than local community or iwi identities.

Today, Māori performing arts is experienced and enjoyed by people in the international community who use performance as a gateway to experience New Zealand. It is common for visiting international students studying in New Zealand on exchange programs to enroll in a course about New Zealand history and culture to gain an understanding of the society with which they are now being educated. This was evident in the two "Introduction to Māori Performing Arts" class' (PERF 151) that I attended in 2010 and 2014 that included many international undergraduate students who were there to gain an understanding of Aotearoa New Zealand culture. Most students felt that enrolling in a Māori music performance class gave them access to a Māori narrative of New Zealand history that they may not have had access to in a European-centric history academic course. Learning and performing waiata, haka and mōteatea introduced students to Māori knowledge and Māori ways of conceptualising the world. Participants felt a stronger connection to and understanding of Aotearoa New Zealand culture and society. The physical act of experiencing a performance art that is "unique" to New Zealand allows international communities to connect with the nation.

There are a number of future research streams that are necessary to fully explore Māori performing arts in Aotearoa New Zealand. More ethnographic research is required on how local communities utilise Māori performing arts. While this thesis investigates te reo acquisition as one component of participation, there is a need to pinpoint the role that Māori performing arts can have in te reo revitalisation, particularly within a political discourse considering the recent debate surrounding compulsory Māori language in schools. Following from this is a need for research into the role the public sector should have in promoting and maintaining Māori performing arts participation; are Māori performing arts composers/ experts/specialists comfortable with nationwide ownership? Building on this thesis, a broader examination of non-Māori performance contexts will enrich our understanding of how indigenous performing arts is used to represent the country; past research of non-Māori participation has primarily focused on performing arts within rugby representations.

Māori performing arts makes a valuable contribution to Aotearoa New Zealand society and allows a diversity of people to access and formulate individual meanings. It works as a medium to promote biculturalism and help foster a more cohesive and inclusive society. Aotearoa needs mechanisms like Māori performing arts as it normalises Māori culture within 
New Zealanders consciousness and promotes a balanced bicultural society. Wānanga and whare tapere are spaces where knowledge is openly shared between Māori and non-Māori. These performance contexts require a collaborative effort between Māori who mediate the knowledge, and non-Māori who willingly engage with Māori culture. These contexts demand a symbiotic relationship, which may feed into other area of New Zealand society. Non-Māori participation in Māori performing arts can be used as a mechanism to stimulate more embracing attitudes towards Māori protocol. By weaving local nation and international connections, Māori performing arts provides a powerful way to engage with Aotearoa New Zealand community. 


\section{Bibliography}

About Kapa Haka. (n.d.). Retrieved April 21, 2014 from http://www.tematatini.co.nz/aboutkapa-haka/

Ainsworth, H. (1993). Rhythm in New Zealand English. (Unpublished Manuscript). Victoria University of Wellington, NZ.

Armstrong, A. (2005). Māori Games \& Haka: Instructions, Words \& Actions (New ed.). Auckland: Reed.

Anderson, B. (2006). Imagined Communities: Reflections on the Origin and Spread of Nationalism. New York: Verso.

Barnes, A. (2013). What Can Pākehā Learn From Engaging in Kaupapa Māori Educational Research? (Vol. 1.). Wellington: New Zealand Council for Education Research.

Barney, K. (2012). Conversations, Collaborations and Contestations: Building a Dialogue Between Indigenous and Non-Indigenous Australians in Ethnomusicological Research. Altitude, 10,1-20.

(2013). Lexine Solomon: Songs of Connection and Celebration by a Torres Strait Islander. University of Illinois Press. Retrieved from http://espace.library.uq.edu.au /view/UQ:302998

Barney, K., \& Solomon, L. (2009). Looking Into the Trochus Shell: Autoethnographic Reflections on a Cross-Cultural Collaborative Music Research Project. In B. Bartleet (Ed.), Musical Autoethnographies: Making Autoethnographies Sing/Making Music Personal (pp. 208-225). Queensland: Australian Academic Press.

Batt-Rawden, K., \& Denora, T. (2005). Music and Informal Learning in Everyday Life. Music Education Research, 7(3), 289-304.

Best, E. (1925). Games and Pastimes of the Ma ori: an Account of Various Exercises, Games and Pastimes of the Natives of New Zealand, as Practised in Former Times: including some Information Concerning Their Vocal and Instrumental Music. Wellington: Te Papa Press.

Biddle, T. (2010). MAOR 125 Special Topic: Māori Performing Arts and Society and MUSC 151 Music in New Zealand [class handout]. Te Kawa a Māui, Victoria University, Wellington.

(2010). Interview by Melissa Cross. Victoria University, Wellingon.

(2012). The Power of Performance: The Constancy of Māori Expressional Culture. In D. Keenan (Ed.). Huia Histories of Māori (pp. 57-72). Wellington: Huia Publishers.

Bishop, R. \& Glynn, T. (1992). Ha Kanohi Kitea: Conducting and Evaluating Educational Research. New Zealand Journal of Educational Studies, 27(2), 125-135.

Bishop, R. (1997). Māori People's Concerns About Research Into Their Lives. History of Education Review, 26(1), 25-41. 
Brettell, C. (Ed.). (1993). When They Read What We Write: the Politics of Ethnography. Westport: Bergin \& Garvey.

Brown, H. (2008). Nga Taonga Takaro: Māori Sports and Games. Auckland: Penguin Group New Zealand Limited.

-- (2012). Restoring Te Reo Māori Means Listening to Our Youth. New Zealand Physical Educator, 45(3), 23-24.

Brown, J. (2006, July 26). Pākehā Urged to Pronounce Place Names Properly. New Zealand Herald Retrieved from http://www.nzherald.co.nz/bay-of-plenty-times/news/article.cfm? c_id=1503343\&objectid $=10942407$

Callanan, M., Cervantes, C., \& Loomis, M. (2011). Informal Learning. Wiley Interdisciplinary Reviews: Cognitive Science, 2(6), 646-655.

Calman, R. (2013, July 12). Māori Education - Mātauranga - Missionaries and the Early Colonial Period. Te Ara - the Encyclopedia of New Zealand.

Carpenter, V. M., \& McMurchy-Pilkington, C. (2008). Cross-Cultural Researching: Māori and Pākehā in Te Whakapakari. Qualitative Research, 8(2), 179-196.

Chatham-Carpenter, A. (2010). "Do Thyself No Harm": Protecting Ourselves as Autoethnographers. Journal of Research Practice, 6(1), 1-13.

Chernoff, J. M. (1979). African Rhythm and African Sensibility: Aesthetics and Social Action in African Music. Chicago: University of Chicago Press.

Clements, D. (1998). The Story of the Haka. Hamilton: The Haka Book Limited.

Cook, N. (2014). Beyond the Score: Music as Performance. London: Oxford University Press.

Cooper, G. (2012). Kaupapa Māori Research: Epistemic Wilderness as Freedom? New Zealand Journal of Educational Studies, 47(2), 64-73.

Cottrell, S. (2004). Professional Music-Making in London: Ethnography and Experience. Burlington: Ashgate.

Cram, F. (1993). Ethics in Māori Research: Working Paper. University of Auckland, Auckland.

Cross, M. (2010). Imagining Ourselves: Māori Music as an Example of the Present and Absent Voices of Cultural Discourse in New Zealand University Music Departments. (Unpublished paper). Victoria University of Wellington.

Cunningham, C. (2000). A Framework for Addressing Māori Knowledge in Research, Science and Technology. Pacific Health Dialog : A Publication of the Pacific Basin Officers Training Program and the Fiji School of Medicine, 7(1), $62-69$.

Davidson, J. M. \& Starzecka, D. C. (1996). Maori: Art and Culture. Auckland: David Bateman Publishing.

Durie, M. (1996): Mātauranga Māori: Iwi and the Crown. (Unpublished discussion paper). 
Ellenbogen, K. M. (2002). Museums in Family Life: An Ethnographic Case Study. In G. Leinhardt, K. Crowley \& K. Knutson (Eds.). Learning Conversations in Museums (pp. 81-101). Mahwah: Lawrence Erlbaum Associates.

Fishman, J. A. (1991). Reversing Language Shift: Theoretical and Empirical Foundations of Assistance to Threatened Languages. Multilingual Matters.

Fox, A. (2004). Real Country: Music and Language in Working-Class Culture. Durham: Duke University Press.

Gardiner, W. (2001). Haka: A Living Tradition. Auckland: Hodder Moa Beckett.

Giorgi, A. P., \& Giorgi, B. M. (2003). The Descriptive Phenomenological Psychological Method. In P. M. Camic, J. E. Rhodes, \& L. Yardley (Eds.), Qualitative Research in Psychology: Expanding Perspectives in Methodology and Design (pp. 243-273). Washington: American Psychological Association.

González, C. M. (2010). "Be(com)ing” Nga ti Kahungunu in the Diaspora: Iwi Identity and Social Organisation in Wellington. (Unpublished Master's thesis). Victoria University of Wellington.

Grace, P. (2001). The Silent Migration: Ngati Pōneke Young Maori Club 1937-1948: Stories of Urban Migration. Wellington: Huia Publishers.

Grace, W. (2011). Ka Mate the Haka the Legend [documentary]. New Zealand: Marema Limited

Greensill, H. (2007). The Relevance of Discourse Analysis to the Teaching and Learning of Te Reo Maori: A Text-Centred Example. Journal of Maori and Pacific Development, 8(1), 3-19.

Horwitz, R. P. (1996). Just Stories of Ethnographic Authority. C. B. Brettell (Ed.). In When They Read What We Write: The Politics of Ethnography (pp. 31-43). Westport: Bergin and Garvey.

Hill, R., \& May, S. (2013). Non-Indigenous Researchers in Indigenous Language Education: Ethical Implications. International Journal of the Sociology of Language, 21(9), 47-65.

Higgins, L. (2012). Community Music: In Theory and In Practice. New York: Oxford University Press.

Hooks, B. (1992). Black Looks: Race and Representation. Hoboken: Taylor and Francis. Jackson, S. J., \& Hokowhitu, B. (2002). Sport, Tribes, and Technology: The New Zealand All Blacks Haka and the Politics of Identity. Journal of Sport \& Social Issues, 26(2), 125-139.

Ka'ai-Mahuta, R. (2008). The Impact of Language Loss on the Māori Performing Arts. Te Kabaroa, 1(1), 165-173.

(2010). He Kupu Tuku Iho Mō Tēnei Reanga: a Critical Analysis of Waiata and Haka as Commentaries and Archives of Māori Political History. (Unpublished doctorate). Auckland University of Technology.

Ka'ai-Oldman, T. (1988). A History of New Zealand Education from a Maori Perspective. In Hirsh, W. \& Scott, R. (Eds.). Getting It Right - Aspects of Ethnicity and Equity in New Zealand Education (pp. 22- 29). Auckland: The Office of Race Relations Conciliator.

Ka'ai, T. (2005). Indigenising the Academy: Indigenous Scholars as Agents of Change. (Unpublished Paper). 
Ka'ai, T., Ka'ai-Mahuta, R., \& Moorfield, J. C. (Eds.). (2013). Kia Rōnaki: the Māori Performing Arts. Auckland: Pearson.

Kāretu, T. S. (1993). Haka: Te Tohu o Te Whenua Ra Ngātira - the Dance of a Noble People. Auckland: Reed.

Kāretu, T., Waite, J. (1988) Te Reo Māori, (New Zealand Official Yearbook 1988-1989). Wellington, Department of Statistics.

Karini, A. (2009). The Status of Contemporary Māori Music. (Unpublished Master's thesis). Massey University, Palmerston North.

Keenan, D. (Ed.). (2012). Huia Histories of Māori: Ngā Tāhuhu Kōrero. Wellington: Huia.

Lassiter, L. E. (1998). The Power of Kiowa Song: A Collaborative Ethnography. Tucson: University of Arizona Press.

(2001). From "Reading over the Shoulders of Natives" to "Reading Alongside Natives," Literally: Toward a Collaborative and Reciprocal Ethnography. Journal of Anthropological Research, 57(2), 137-149. 46(1), 83-106. (2005a). Collaborative Ethnography and Public Anthropology. Current Anthropology, (2005b). The Chicago Guide to Collaborative Ethnography. Chicago: University of Chicago Press.

Leinhardt, G., Crowley, K., \& Knutson, K. (Eds.). (2002). Learning Conversations in Museums. Mahwah: Lawrence Erlbaum.

Lyons, E., \& Coyle, A. (2008). Analysing Qualitative Data in Psychology. London: Sage Publications Ltd.

Maaka, R. (2003). Perceptions, Conceptions and Realities: a Study of the Tribe in Maori Society in the Twentieth Century. (Unpublished doctoral thesis). University of Canterbury, Canterbury.

Mahuika, R. (2008). Kaupapa Māori Theory is Critical and Anti-Colonial. MAI Review, (3), 1-16.

Manatū Taonga Ministry for Culture and Heritage (2014). Ngā Hua A Tāne Rore: the Benefits of Kapa Haka [report]. Wellington: Author.

McLean, M. (1971). Mãori music. Wellington: School Publications Branch.

(1999). Of warriors and Blokes: The Problem of Māori Rugby for Pakeha Identity in New Zealand. In T. Chandler \& J. Nauright (Eds.). Making the Rugby World: Race, Gender and Commerce (pp. 1-26). London: Frank Cass.

(2004). Traditional Songs of the Māori (3rd ed.). Auckland: Auckland University Press.

Mead, H. M. (2003). Tikanga Maori: Living by Maori Values. Wellington: Huia Publishers.

Mihaka, R. (2008). Te Reo Māori Can Be Easily Learned Through Waiata Tamariki. Good Practice Publication Grant Scheme. 
Mita, D. M. (2007). Māori Language Revitalization: A Vision for the Future. Canadian Journal of Native Education, 30(1), 101-107.

Murray, D. A. B. (2000). Haka Fracas?: The Dialectics of Identity in Discussions of a Contemporary Maori Dance. Australian Journal of Anthropology, 11(3), 345-357.

Ngata, R. (2002). Māori Action Songs Words and Music, Action and Instructions. Auckland: Reed.

Nunan, D. (1991). Language Teaching Methodology: A Textbook for Teachers. New Jersey: Prentice Hall.

Paenga, M. D. T. A. (2008). Te Māoritanga: Wellbeing and Identity: Kapa Haka as a Vehicle for Māori Health Promotion (Unpublished Master's thesis). Auckland University of Technology (AUT), Auckland.

Peters, E. J., \& Andersen, C. (Eds.). (2013). Indigenous in the City: Contemporary Identities and Cultural Innovation. Vancouver: UBC Press.

Peters, M. H. (2014). Reclaiming the Māori Language for Future Generations: Flax Root Perspectives. Tîkina te Mana o Te Reo Māori: Te Pūtaketanga o Te Pā Harakeke. (Unpublished doctorate dissertation). University of Waikato, Hamilton.

Oliver, S. (2012). Te Rauparaha. Retrieved June 28, 2014 from http://www.TeAra.govt.nz/en/ biographies/ 1t $74 /$ te-rauparaha

Rice, T. (1994). May It Fill Your Soul: Experiencing Bulgarian Music. Chicago: University of Chicago Press.

Roberts, A. (2011, May 3). Toddlers Get Immersion in Kapa Haka. The Nelson Mail. Retrieved from http:// search.proquest.com.helicon.v uw.ac.nz/docview/867055812

Rogoff, B., Paradise, R., Arauz, R. M., Correa-Chavez, M., \& Angelillo, C. (2003). Firsthand Learning Through Intent Participation. Annual Review of Psychology, 54, 175-203.

Royal, C. (1998). Mātauranga Māori Paradigms and Politics. A paper presented to the Ministry for Research, Science and Technology. Wellington, New Zealand.

(2007) Mātauranga Māori and Museum Practice: A Discussion by Dr Charles Royal. [report]. Wellington: Museum of New Zealand Te Papa Tongarewa.

(2009, November). Mōteatea: Traditional Māori Song Poetry. Paper presented at the Oceania, World Music Days, International Symposium and Festival Dialogue in Music, Beijing, China. Retrieved from http://www.charles-royal.com/assets/mōteateatraditionalsongpoetry.pdf

(2012). Politics and Knowledge: Kaupapa Maori and Mātauranga Maori. New Zealand Journal of Educational Studies, 47(2), 30-37.

Royal-Tangaere, A. (1997). Mai i Rangiatea: Māori Wellbeing and Development. New York: Teachers College Press.

Sakamoto, F. (2012, December). Kapa Haka and Its Education Meanings In Today's Aotearoa New Zealand. International Indigenous Development Research Conference 2012. 
Salter, G. (2000). Culturally Responsive Pedagogy and the Renaissance of a Māori Dimension in Physical Education: Te Reo Kori as Cultural Taonga. Journal of Physical Education New Zealand, 33(2), 42.

Schieffelin, B. B., \& Ochs, E. (1986). Language Socialization Across Cultures. Cambridge: Cambridge University Press.

Shelemay, K. K. (2011). Musical Communities: Rethinking the Collective in Music. Journal of the American Musicological Society, 64(2), 349-390.

Shennan, J. (1984). The Māori Action Song: Waiata a Ringa, Waiata Kori, no Whea Tenei Abua Hou? Wellington: New Zealand Council for Educational Research.

Smith, J. A., \& Eatough, V. (2007). 3 Interpretative Phenomenological Analysis. In Analysing Qualitative Data in Psychology (pp. 35-50). London: SAGE Publications Ltd.

Smith, L. T. (2009). Decolonizing Methodologies: Research and Indigenous Peoples. New York: Zed Books.

Smith, L. T. (2012). Decolonizing Methodologies: Research and Indigenous Peoples (2nd ed.). New York: Zed Books.

Sposet, B. A. (2008). The Role of Music in Second Language Acquisition: a Bibliographical Review of Seventy Years of Research, 1937-2007. Lewiston: E. Mellen Press.

Szakay, A. (2007). Identifying Maori English and Pakeha English from Suprasegmental Cues: A Study Based on Speech Resynthesis. (Unpublished Master's thesis). Univesity of Canterbury, Canterbury.

Tapine, V., \& Waiti, D. (1997). Visions for Māori Education. Wellington: New Zealand Council for Educational Research.

Tauroa, H., \& Tauroa, P. (1986). Te Marae: A Guide to Customs \& Protocol. Auckland: Reed Methuen.

Te Matatini. (n.d.). Te Matatini Kapa Haka Aotearoa. Retrieved March 28, 2014, from http:// www.tematatini.co.nz

Te Puni Kōkiri. (2006). The Health of the Māori Language in the Arts Sector [report].

Wellington: Author.

The Ministry of Culture and Heritage. (2014). New Zealand Natives' Rugby Tour of 1888-9. Retrieved July 4, 2014 from http://www.nzhistory.net.nz/culture/the-new-zealand-natives-rugbytour/nz-natives-rugby-tour

Tucker, L., \& Mantie, R. (2006). Community: Music: Making: Connections. The Canadian Music Educator, 48(2), 34-39.

Turino, T. (2008). Music as Social Life: the Politics of Participation. Chicago: University of Chicago Press.

Tuan, Y. (1977). Space and Place: the Perspective of Experience. Minneapolis: University of Minnesota Press.

Vygotskii, L. S. (1978). Mind in Society: the Development of Higher Psychological Processes. Cambridge: Harvard University Press. 
Waitoa, H. (1970). He Waiata haka = Modern Action Songs. Wellington: Victoria University of Wellington Department of Anthropology.

Walker, R. (1996, October). Te Karanga: Haka History. Metro (125).

Whitinui, P. (2008a). The Indigenous Factor: Exploring Kapa Haka as a Culturally Responsive Learning Environment in Mainstream Secondary Schools. (Unpublished doctorate dissertation). University of Auckland, Auckland.

(2010). Indigenous-based Inclusive Pedagogy: The Art of Kapa Haka to Improve Educational Outcomes for Maori Students in Mainstream Secondary Schools in Aotearoa, New Zealand. International Journal of Pedagogies \& Learning, 6(1), 3-22.

Whitinui, P. (Ed.). (2011). Kia Tangi Te Tìtī: Permission to Speak: Successful Schooling for Māori students in the 21st Century: Issues, Challenges and Alternatives. Wellington: NZCER Press.

Williams, D. (1997). Mātauranga Māori and Taonga: The Nature and Extent of Treaty Rights Held by Iwi and Hapü. Auckland University: Waitangi Tribunal Report for the Wai 262 claim.

Wong, D. A. (2004). Speak It Louder: Asian Americans Making Music. New York: Routledge.

Zavos, S. (1998). Ka Mate! Ka Mate! New Zealand's Conquest of British rugby. Auckland: Viking.

\section{Interviews}

Beamsley, Trish (2014). Personal interview. June 23. Wellington, New Zealand

Dustow, Tim (2014). Personal interview. May 22. Wellington, New Zealand

Forde, Julia (2014). Personal interview. June 13. Wellington, New Zealand

George, Max (2014). Personal interview. June 12. Wellington, New Zealand

Harrison, Tarryn (2014). Personal interview. June 5. Wellington, New Zealand

Katene, Tamihana (2014). Personal interview. August 21. Wellington, New Zealand

Mitchell, Abigail (2014). Personal interview. June 5. Wellington, New Zealand

Morton, Naomi (2014). Personal interview. June 5. Wellington, New Zealand

Patel, Payal (2014). Personal interview. May 28. Wellington, New Zealand

Royal, Keriata (2014). Personal interview. June 12. Wellington, New Zealand

Ryder, Eugene (2014). Personal interview. July 27. Wellington, New Zealand

Teina May, Miriama (2014). Personal interview. June 19. Wellington, New Zealand 
